\title{
THE TIPULA (ACUTIPULA) MAXIMA GROUP (INSECTA, DIPTERA, TIPULIDAE)
}

\section{TAXONOMY AND DISTRIBUTION}

\author{
by \\ DICK VERMOOLEN \\ Institute of Taxonomic Zoology (Zoölogisch Museum), P.O. Box 20125, 1000 HC Amsterdam, The Netherlands
}

\section{SUMMARY}

A systematic account is presented of the species of the Tipula (Acutipula) maxima group. To the eleven species and subspecies already known, six are added as new: maxima balcanica. transcaucasica latifurca, libanica, cretensis, isparta, and cypriensis. Of all taxa the genital structures of the males and females are described and figured. These structures allow a grouping of the species into five subgroups. The distribution of the species and subspecies is mapped; they are all limited to smaller areas in the Mediterranean region, but for maxima itself which occupies almost entire Europe.

\section{RÉSUMÉ}

On présente une mise au point systématique des espèces de Tipula (Acutipula) appartenant au groupe de maxima. Six espèces et sous-espèces nouvelles sont ajoutées aux onze déjà connues; il s'agit de: maxima balcanica, transcaucasica latifurca, libanica, cretensis, isparta, et cypriensis. Les structures génitales des mâles et des femelles de tous ces taxa sont décrites et figurées. L'étude de ces structures permet de grouper les espèces en cinq sous-groupes. Des cartes sont données pour la distribution des espèces et sous-espèces; elles sont toutes limitées à des zones restreintes de la région méditerranéenne, à l'exception de maxima, présente presque dans l'ensemble de l'Europe.

\section{INTRODUCTION}

The Tipula (Acutipula) maxima group contains 17 species and subspecies. The group, defined by the very characteristic wing pattern (figs. 1-3), is named after Tipula maxima Poda, 1761. This species has a large distribution throughout Europe (map 1). All the other species are restricted to the circum-Mediterranean region. Three species occur in the Iberian Peninsula, five in northern Africa, three in Italy and adjacent islands, three in the southern Balkans and Greece, and five in Asia Minor.
Specimens are usually found in shrubs and forests along small streams and rivers, most frequently in mountainous areas, but also in less accidented areas such as dunes.

All species of this group can be recognized by the specificity of their hypopygial structures. Other diagnostic features are mainly restricted to the intensity of the body colouration and the pattern of the wing markings. In this study an attempt has been made to describe the females as well, especially by drawings of the copulatory and ovipository organs, which were hitherto neglected in studies of this group. These structures, although sometimes difficult to examine, show very reliable characters for separating species. The drawings presented here are made after specimens that are macerated in nearly boiling $10 \%$ potassium hydroxide for approximately 10 minutes. Therefore, comparison of dried specimens with these illustrations is sometimes less instructive.

Throughout the text the different markings of the wing are named $\mathrm{S} 1$ to $\mathrm{S} 5$ as exemplified in fig. 1. Wing cells are given in capitals, wing veins in lowercase. Fig. 15 shows the numbering of the parts of the inner dististyle (Id).

\section{MATERIAL}

Most of the material examined is incorporated in the Institute of Taxonomic Zoology (Zoölogisch Museum), Amsterdam; the Zoologisches Forschungsinstitut und Museum Alexander Koenig (Kollektion Mannheims), Bonn; the British Museum (Natural History), London; the Muséum National d'Histoire Naturelle (Collections Meigen and Pierre), Paris. Abbreviations for all the museums from which material has been studied are listed below. 
As far as possible the type-material of the species treated here has been examined. The full data of the typespecimen labels are provided between quotation marks. Also all other specimen labels, if necessary to be mentioned, are cited literally.

The distributions, based on the material examined and on an evaluation of the literature, are exemplified by maps. All drawings are made by the author, except for figs. 1-3 which have been executed by $A$. A. Weijde.

\section{ABBREVIATIONS}

In the text and drawings the following abbreviations are used:

$\begin{array}{ll}\text { a } & \text { anal vein } \\ \text { cu } & \begin{array}{l}\text { cubital vein, cubitus } \\ \text { crossvein medius-cubitus }\end{array} \\ \text { mcu } & \text { medial vein, medius } \\ \text { m } & \text { basal part of radius } \\ \text { rs } & \text { medius cell } \\ \text { M } & \text { radius cell } \\ \text { R } & \text { wing spot } \\ \text { S } & \text { sternite } \\ \text { ST } & \text { tergite } \\ \text { T } & \text { outer dististyle } \\ \text { Od } & \text { inner dististyle }\end{array}$

BMNH British Museum (Natural History), London

MAK Zoologisches Forschungsinstitut und Museum Alexander Koenig, Bonn

MNHNP Muséum National d'Histoire Naturelle, Paris NMW Naturhistorisches Museum, Wien (Vienna)

RMNH Rijksmuseum van Natuurlijke Historie,

ZMA Instituut voor Taxonomische Zoölogie (Zoölogisch Museum), Amsterdam

\section{GROUP CHARACTERS}

The species of the maxima group share a great number of characters. These characters are enumerated below and will not be repeated with the descriptions of the species.

Head: Antennae 13-segmented, in male and female of equal length, about three times the length of the rostrum, folded backwards not reaching beyond the wing base; scape cylindrical; pedicel bulb-shaped; flagellar segments pubescent, somewhat enlarged basally; verticils about 1.5 times the length of the flagellar segments; rostrum and vertex light brown to grey-brown; nasus dark brown, hirsute and about 0.5 to 0.6 times the length of the scape; palps usually darker than the rostrum; eyes ventrally close together, at a distance of about 1.5-2 times the diameter of the scape, except in $T$. triangulifera, $T$. repanda and $T$. doriae, where the distance is about 1 , in $T$. macra where it is in between 3 and 3.6 and $T$. anormalipennis where it is in between 3 and 3.9.

Thorax: Ground colour of prescutum yellowbrown to red-brown, prescutum with four brown to grey-brown longitudinal stripes which are slightly darker along the borders; pleura yellow to grey-brown with lateral prescutal and scutal borders brownish to dark brown; katatergite, anatergite and the basal parts of pteropleurite, anepisternite, sternopleurite and meron vaguely brownish; coxae yellowish, with long hairs; legs long and slender, yellow to brown at the end of femora and tibiae, the apical margin of the femora with a dense row of setae (fig. 4), somewhat resembling the crest of setae as found in Holorusia; spine formula on femora 1-2-2; male tarsal claws toothed at the bases as well as in the middle (fig. 6), except in $T$. anormalipennis where the claws are untoothed as in females (fig. 5).

Wings: Whitish to yellow-greyish, subhyaline, conspicuously marked brown (fig. 1); at the anterior wing margin three brown spots, the first (S1) at the wing base is somewhat rectangular, the second (S2) in the middle is about triangular and the third (S3) at the wing tip has more or less straight margins; the posterior wing margin is provided with several pale brownish spots in the $\mathrm{M}$ cells and the anal cells, the spots in the anal cells are roughly divided into two by vein a2; the spot at the fork of cumcu-cu1 (S4) is connected along cu with S2; the $\mathrm{Cu}$ cell contains a small dark spot (S5) in between S1 and S2; the discoid cell is usually partially coloured distally; M1 with a petiole of about 1/4-1/5 the length of $\mathrm{m1}$; squamae with a few small setae; rs hardly longer than mcu.

Halteres: Brownish, the base of the stem firmly hirsute, the knobs centrally darkened and scarcely brightened at apex. 

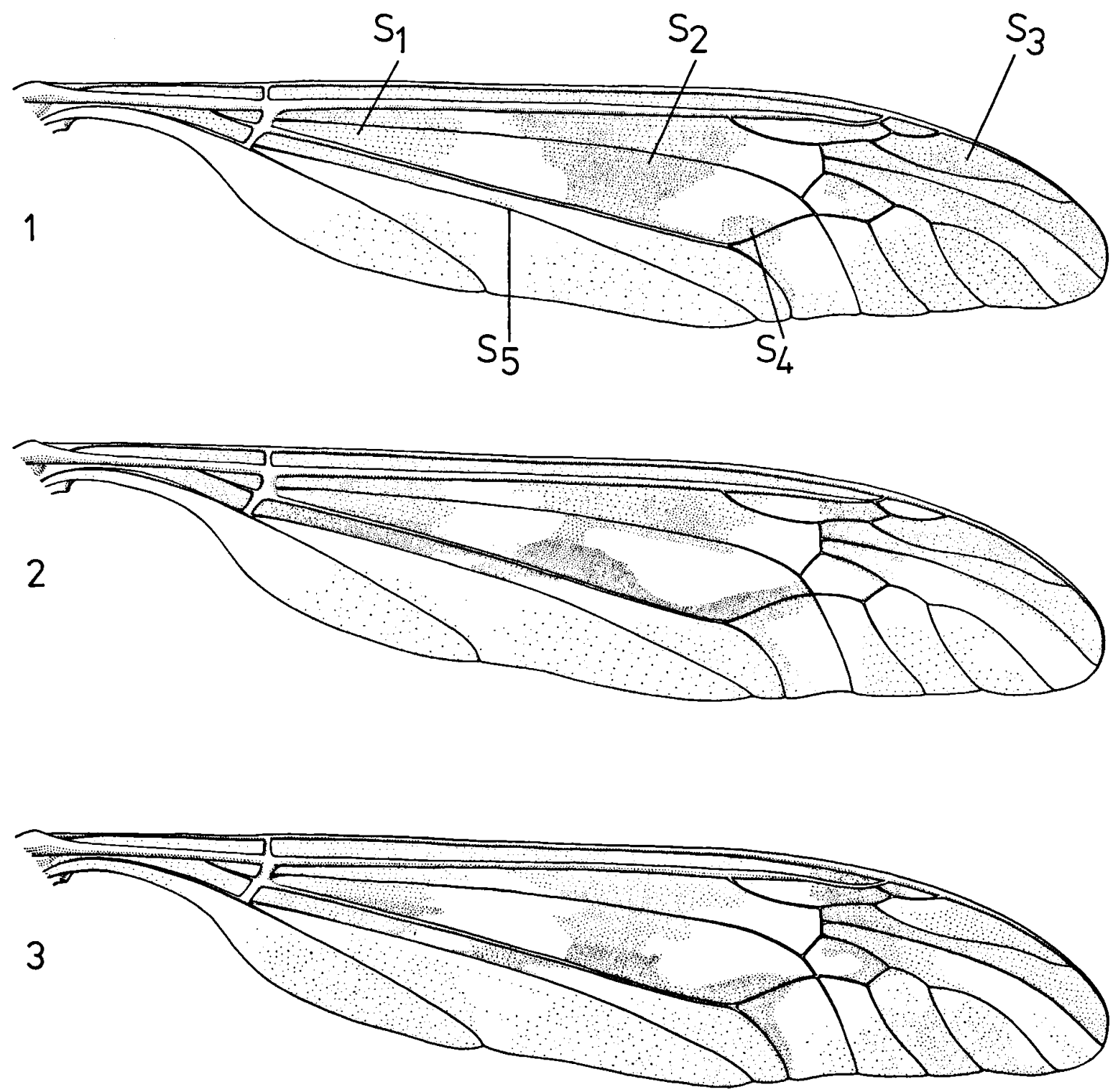

Figs. 1-3. Wing pattern: 1, T. (A.) maxima maxima Poda, 1761 (for explanation see text); 2, T. (A.) corsica Pierre, 1921; 3, T. (A.) doriae Pierre, 1926.

Abdomen: Slender, in the male shorter than the wings, in the female about as long or (usually) longer; ground colour rusty to greyish brown, male hypopygium darker and female ovipositor lighter than abdomen, both with narrow lateral and narrow dorsal stripes; margins of the segments yellowish; tergite 9 of male fused with sternite 9 (as in other species groups of Acutipula) but with a distinct fold in between; posterior border of male tergite 9 produced into two slender lateral lobes or spines and one or two short medial lobes which bear small spines such as in Tipula and Yamatotipula; outer dististyle (Od) whitish to yellow-greyish, with many very small setae, about oval and with obtuse apex; inner dististyle (Id) consisting of four more or less hooked processes or projections which are very characteristic of every species 

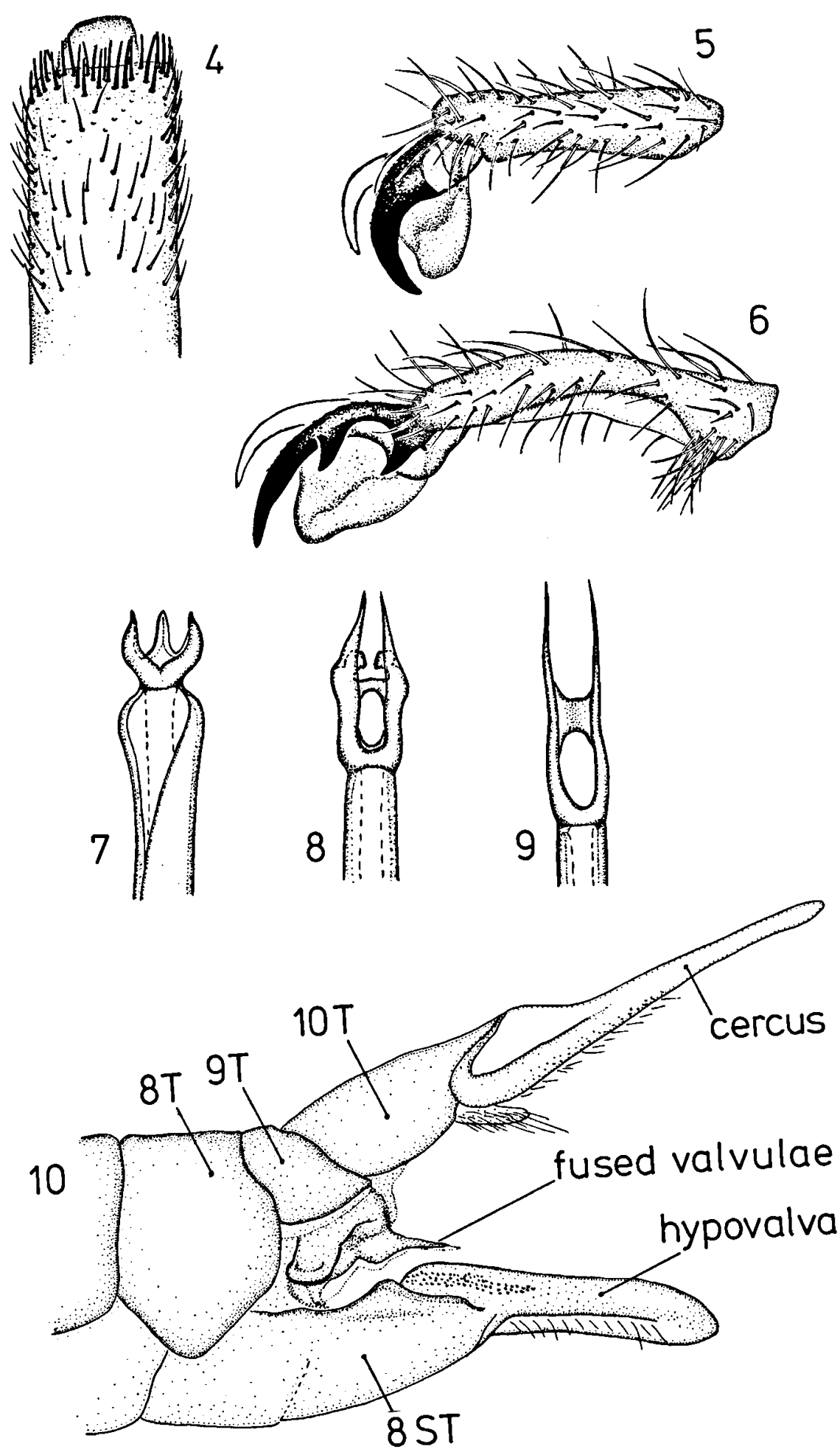

Figs. 4-10. Fig. 4, apex of tibia of $T$. (A.) maxima maxima Poda, 1761, dorsal view. Figs. 5-6, tarsal claws of $T$. (A.) repanda Loew, 1864, lateral view: 5 , untoothed $\$$ claw; 6 , $\sigma^{\circ}$ claw with basal and medial tooth. Figs. 7-9, apex of intromittent organ, dorsal view: 7, tridental (maxima subgroup, corsica subgroup); 8, bispicate with two small hooklets (doriae subgroup); 9, bispicate (repanda subgroup, anormalipennis subgroup). Fig. 10, 9 ovipositor of $T$. (A.) maxima maxima, lateral view. 
and subspecies; female ovipositor with tergite 9 and sternite 9 not fused entirely, tergite 9 and sternite 8 occluding in a very species-specific way; hypovalvae shorter than the cerci, the former reaching up to about $1 / 2$ to $2 / 3$ of the cerci (fig. 10).

\section{SPECIES GROUPS}

The 17 species and subspecies of the maxima group are assigned to five subgroups. These subgroups are based on shared characters found in the male and female copulatory organs. The monophyly of these groups is not yet established and will be dealt with in a special paper on phylogeny. The following subgroups can be distinguished:

1: maxima subgroup:

T. maxima maxima (northwestern Europe and Italy)

T. maxima pseudogigantea stat. nov. (Iberia)

$T$. maxima balcanica subspec. nov. (southeastern Europe)

T. transcaucasica transcaucasica stat. nov. (southeastern Europe, Asia Minor)

T. transcaucasica latifurca subspec. nov. (southeastern Europe, Asia Minor)

T. libanica spec. nov. (Lebanon)

2: corsica subgroup:

T. corsica (Corsica)

T. rifensis (northern Africa)

T. cretensis spec. nov. (Crete)

T. macra (Asia Minor)

3: doriae subgroup:

T. doriae (Giglio, Corsica, Sardinia)

T. isparta spec. nov. (Turkey, Cyprus)

$T$. cypriensis spec. nov. (Cyprus)

4: repanda subgroup:

T. repanda (Iberia)

T. triangulifera (Iberia)

T. repentina (northern Africa)

5: anormalipennis subgroup:

T. anormalipennis (northern Africa)

\section{Tipula (Acutipula) maxima subgroup}

This first section contains Tipula maxima Poda, divided here into three subspecies, Tipula transcaucasica Savtshenko with two subspecies and a new species, $T$. libanica.

Apparently, this subgroup is closely related to the corsica subgroup with which it shares the special structure at the apex of the intromittent organ (fig. 7). Both subgroups are defined by special characters of the inner dististyle (Id). Most of the eidonomic characters differ only slightly but the male hypopygium and the female ovipositor are very characteristic in order to separate species and subspecies.

\section{Tipula maxima Poda, 1761}

Throughout its range $T$. maxima shows a fair amount of variation in size, colouration and wing pattern. The main characters distinguishing the subspecies are found in the hypopygium and ovipositor, although for example the sclerotized apex of Id1 varies in T. m. maxima in size throughout the whole distribution area (figs. 12, 13), but appear to be small in all Italian specimens. Colouration is a less reliable character as well. Most of the specimens are dark brown to grey, but the Italian ones are coloured light brown to reddish brown. The geographic ranges of the subspecies (map 1) do not overlap. Most of the data by Savtshenko, 1961, can not be assigned to any of the subspecies (see "distribution").

\section{Tipula maxima maxima Poda, 1761}

(Figs. 1, 11-18)

Tipula rivosa Scopoli, 1763: 318 .

Tipula sinuata Fabricius, 1775: 749.

Tipula gigantea Schrank, 1776: 92.

Tipula hortorum Herbst, 1784: 100 (nec Linnaeus, 1758).

Refs.: Poda, 1761: 113; Zetterstedt, 1851: 3914-3916; Puls, 1864: 4; Lundström, 1907: 8; Czerny \& Strobl, 1909: 135; Riedel, 1919: 16; Riedel, 1920: 17; Goetghebuer \& Tonnoir, 1921: 113; Lackschewitz, 1927: 3; Lackschewitz, 1933: 253; Nielsen, 1933: 244; Nielsen, 1941: 95; Tjeder \& Klefbeck, 1946: 207; Mannheims, 1950: 93 (biology); Fischer, 1952: 121; Hemmingsen, 1952: 415-416 (biology); Mannheims, 1952: 102, fig. 54; Mannheims, 1953: 3; Kidd, 1954: 86; Mannheims, 1954a: 152; Mannheims, 1954b: 44; Tjeder, 1955: 244-245; Vaillant, 1956: 

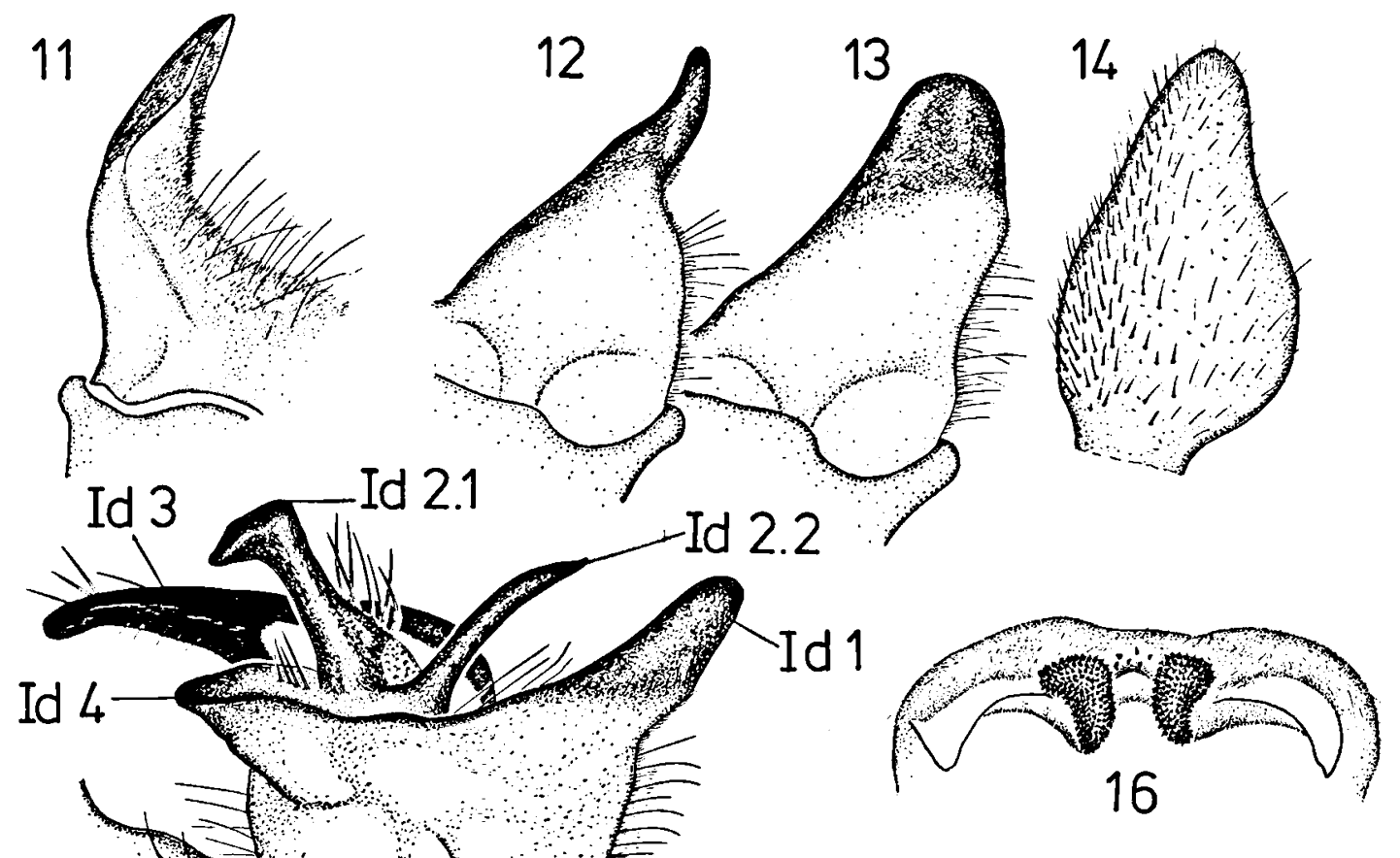

15
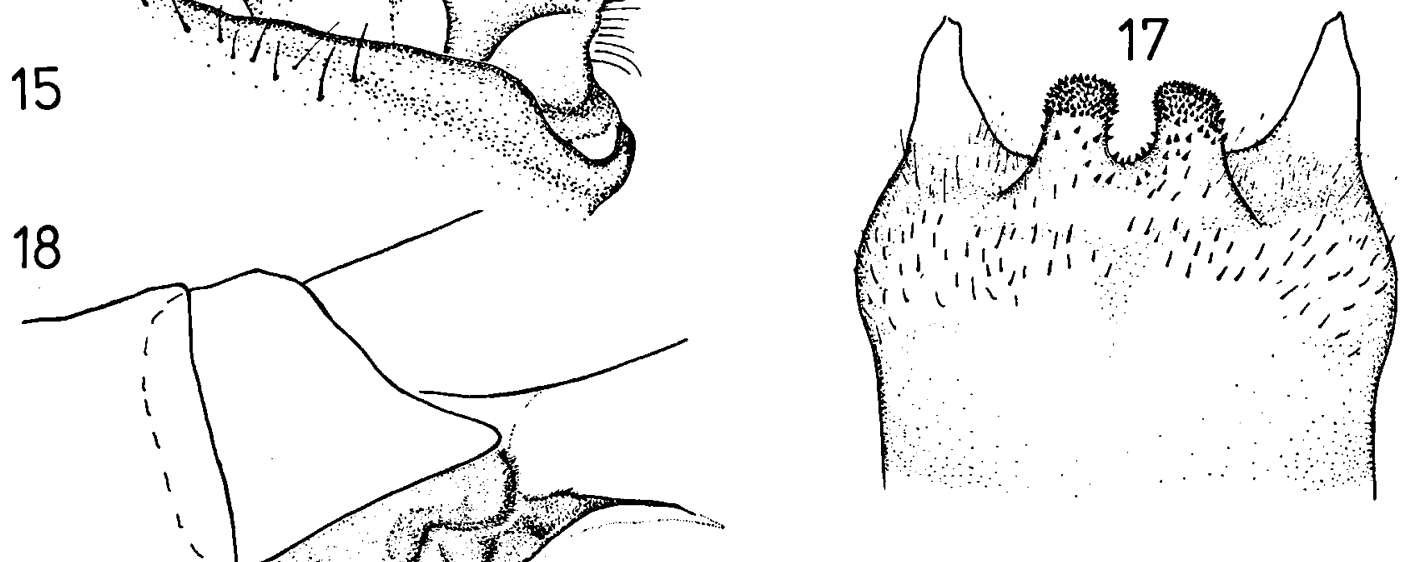

Figs. 11-18. T. (A.) maxima maxima Poda, 1761 ( $\sigma$ from Kärnten, Austria; $९$ from l'Aquila, Italy): 11, $\sigma^{\circ}$ Id part 1, caudointernal view; 12,13 , variation in size of apex of Id1; 14, o Od, lateral view; 15, $\sigma^{\circ}$ Id, lateral view; $16, \sigma^{\circ} \mathrm{T} 9$, caudal view; 17 , ơ T9, dorsal view; 18 , $९$ ovipositor, lateral view. 
162, 176; Theowald, 1957: 18 (biology); Mannheims \& Theowald, 1959: 18; Simova, 1959: 130; Erhan \& Theowald, 1961: 250; Savtshenko, 1961: 409-413, figs. 214, 216, 247-249; Hemmingsen, 1962: 154 (biology); Mannheims \& Pechlaner, 1963: 15 (biology); Mannheims, 1964: 4, fig. 3; Tjeder, 1965: 45; Mannheims, 1966a: 494 (biology); Mannheims, 1966b: 116; Tjeder, 1967: 19; Freeman, 1967: 131; Freeman, 1968: 346; Payne, 1968: 36-37; Mannheims, 1969: 189; Zangheri, 1969: 1025; Hartig, 1971: 125; Theowald, 1971: 221; Dobson, 1974: 514 (biology); Simova, 1974: 26; Steward, 1975: 185; Mannheims * Thomas, 1976: 284-285; Simova, 1976: 149; Caspers, 1977: 202-204 (biology); Simova, 1977: 104-105; Theischinger, 1977: 3; Simova, 1978: 185; Theischinger, 1978: 250; Theowald, 1978b: 365; Hancock, 1979: 24; Dufour, 1980: 15-17; Theowald \& Oosterbroek, 1981: 34 .

Material examined. - The original description of $T$. maxima by Poda (1761) does not mention the number of specimens. It is almost certain that no type-material has been preserved. As maxima is divided into three subspecies, a neotype of maxima maxima is hereby designated. It is chosen from the same area as the original type-locality, Steiermark in Austria. Neotype: $\sigma$, labeled: "Austria, inf. Schwarzau i G, 23-V-15, Zerny" (in NMW).

Other material $\left(2160^{\circ} \circ, 148 \%\right.$ \%) studied from the following countries: Finland (Terijoki, Vichtis), Sweden (Skåne, Öland, Gottland), Great Britain (Cumberland), Ireland (Galway, Connamara), the Netherlands, Belgium, France, Spain (Huesca, Lerida, Barcelona, Gerona, Viscaya), Andorra, Germany, Switzerland, Austria (Tirol, Kärnten, Steiermark), Italy (Genua, Bologna, Aosta, Entrèves, Aquila, Varese, Calabria, Sicily), Czechoslovakia (Bohemia, Moravia), Hungary: $300^{\circ} 0^{\circ}$, $24 \% \&$, examined by Miss A. Valý, Poland: $6 \sigma^{\circ} \sigma^{\circ}, 3$ \& $Q$ examined by Dr. W. Krzeminský.

\section{Description}

Length: $O$ \% 21-29 $\mathrm{mm}$, क 25-38 mm. Wing length ( $\left.\sigma^{\circ}, \%\right)$ : 23-32 mm.

Head: Scape and pedicel brown; flagellar segments light brown; scape apically darkened. Thorax: Wing: S1 trapezoid; stigma redbrownish; R3 whitish at tip; basal half of R4 5 brown, with some white spots near $m 1+2$, the apical part white; discoid cell brown along the veins, sometimes the caudal part half brown; anal spots separated (fig. 1).

Abdomen: Male: Lateral extensions of tergite 9 long and spine-like, medial processes shorter and comma-like with small spicules (figs. 16, 17); Od pear-shaped (fig. 14); Id 1 toothshaped, at base broad and massive, inner side pilose up to apex, outer side of apex sclerotized (fig. 11); Id 2.1 long and slender, projected forwards, at apex abruptly bent downwards; Id 2.2 long and slender, pointed at apex; Id 2 just above the sensory field with 7-11 spine-like setae; Id 3 firmly sclerotized, posterior half flattened, anterior half with several long setae near the apex, apex ventrally with many small setae; Id 4 dorsally flattened and broad, sometimes with a few setae in a row just in front of Id 2 (fig. 15).

Female: Membranous connection between fused valvulae and tergite 9 projected outwards laterally and discoid-like; upper margin of tergite 8 strongly curved; apex of fused valvulae short (fig. 18).

\section{Distribution (map 1)}

Most of the data by Savtshenko (1961) are represented in map 1 by crosses. Savtshenko figures $m$. balkanica but it is not known whether all his localities refer to this subspecies. Only one female is known from Algeria, labeled: "Biskra, Mrch. 13 - April 8. 1914 (W. R. \& E. $\mathrm{H})$ "' (in BMNH).

\section{Biology}

T. m. maxima is frequently found along streams and rivers, in the Netherlands also in the coastal dunes. The larvae live in mud and very wet soils. In the south the period of flight is from March till October with a distinct peak from the end of May till the beginning of June and again at the end of July. In the northern part of the range the period of flight is shorter, from mid-April till the end of July.

Altitudes recorded for $m$. maxima are: France: Pyrénées-Orientales $2000 \mathrm{~m}$, Hautes-Pyrénées 2000 m, Hautes-Alpes 2000 m; Spain: Pyrenees (Gerona) $2100 \mathrm{~m}$; Italy: Calabria $1800 \mathrm{~m}$, Sicily $1800 \mathrm{~m}$.

\section{Tipula maxima pseudogigantea Strobl,} 1900 , stat. nov.

(Figs. 19-22)

Tipula pseudogigantea Strobl, 1900: 207-208. 
Refs.: Strobl, 1900: 207-208; Mannheims, 1951: 103; Savtshenko, 1961: 411.

Material examined. - Strobl described pseudogigantea after one male from Sierra Aiscurre in northern Spain. The holotype specimen is still preserved in the collection Strobl in Admont, Austria (Morge, 1976: 414), but it has not been examined by the author. The characters mentioned by Strobl (body and wing colouration as well as the inner dististyle) are found in all the specimens mentioned below and clearly separate $m$. pseudogigantea from $m$. maxima.

The material examined (30 $\sigma^{\circ}, 9 \%$ 9 ) originates from the following provinces of Spain: Santander $90^{\circ} \sigma^{\circ}, 2$
ㅇ \& (ZMA), Avila 18 ơ ơ, 4 \& \& (ZMA), Madrid 1 \% (ZMA), Cuenca $1 \sigma^{\circ}$ (ZMA), Andalusia 1 \% (NMW), Granada 1 ơ, 2 \& $\%$ (MAK).

\section{Description}

Length: ơ 21-32 $\mathrm{mm}$, ᄋ $23-39 \mathrm{~mm}$. Wing length $\left(\sigma^{\circ}, \$\right): 18-32.5 \mathrm{~mm}$.

Head: Scape, pedicel and flagellar segments somewhat equally brown to dark brown, scape apically dark brown to black; eye distance ventrally 1.5-2.4 times the diameter of the scape,

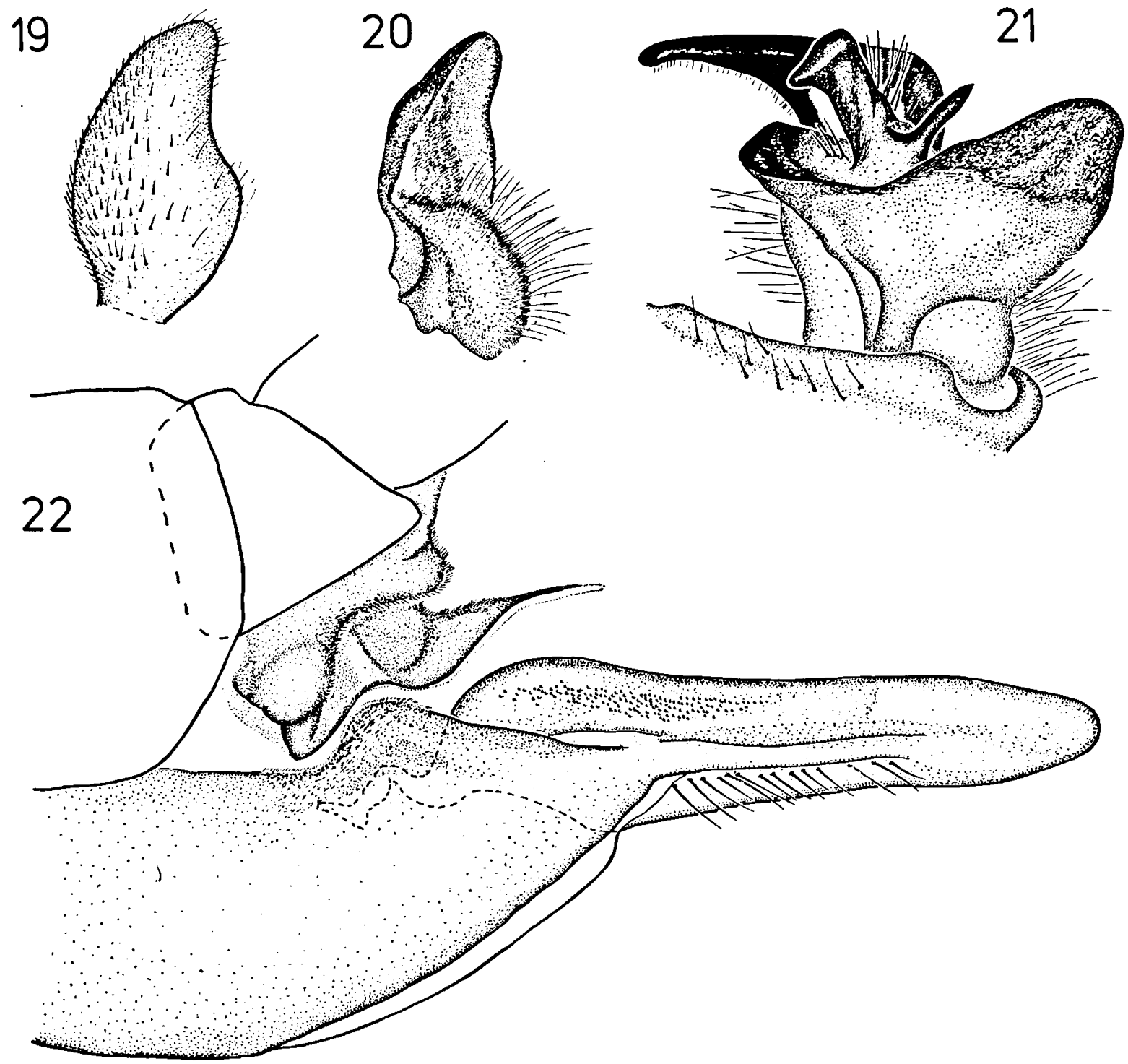

Figs. 19-22. T. (A.) maxima pseudogigantea Strobl, 1900 stat. nov. ( $\sigma^{\circ}, \propto$ from Avila, Spain): 19, $\sigma^{\circ}$ Od, lateral view; 20 , $\sigma$ Id part 1, caudointernal view; 21, $\sigma$ Id, lateral view; 22, $\odot$ ovipositor, lateral view. 
except for the specimens from Sierra Nevada (Granada) where it is about 3.0.

Thorax: Wing: darkened, the white spots as in $m$. maxima, but smaller; $\mathrm{S} 1$ and $\mathrm{S} 2$ separated by a narrow parallel crossline; S4 darkened and broadly extended along cu1 to margin; the apical part of $\mathrm{R} 4+5$ whitish with a small brown spot at the wing margin.

Abdomen: Lateral stripes broad; sternite 1 dark brown to black. Male: Od more pointed than in m. maxima (fig. 19); Id 1 at inner base with a hirsute swelling, the upper part concave, broad and at outer side strongly sclerotized (fig. 20); Id. 2.1 short, laterally broadly flattened, at the inner side with 7-8 spine-like setae above the sensory field; Id 2.2 short, cylindrical and pointed (fig. 21).

Female: Membranous connection between fused valvulae and tergite 9 laterally less discoid-like than in m. maxima; dorsal margin of sternite 8 more broadly rounded than in $m$. maxima; apex of fused valvulae elongate (fig. 22).

\section{Distribution (map 1)}

Apparently limited to the western half of the Iberian peninsula, but not known from Portugal.

\section{Biology}

Like $m$. maxima occurring near running water with muddy shores. Period of flight: April till July with a peak at the end of May till the beginning of June. Recorded altitudes between $600-1600 \mathrm{~m}$, in the Sierra Nevada $2000-2600$ m.

\section{Discussion}

The characters mentioned above easily separate $m$. pseudogigantea from m. maxima. Only one male (Cuenca, Tragacete, 9/6 1980, leg. H. Teunissen) is found intermediate. The colouration of the wings of this specimen is as in $m$. pseudogigantea, whereas the Id1 and Id2 look more like in m. maxima.
3. Tipula maxima balcanica subspec. nov. (Figs. 23-26)

Material examined. - Type-material: Holotype: $\sigma^{\circ}$ from Greece, labeled: "Hellas, Peloponnisos, Vourvoura, $25 \mathrm{~km}$ S. of Tripolis, 9-VII-1977, M. J. \& J. P. Duffels" (ZMA).

Paratypes: $2 \sigma^{\circ} \sigma, 2$ \% $\%$ labeled as the holotype (ZMA); $40^{\circ} 0^{*}, 5$ \& \& Griechenland, Ano kastritsi, 23-V-1979, $600 \mathrm{~m}, 38^{\circ} 16^{\prime} \mathrm{N} 21^{\circ} 50^{\prime} \mathrm{E}$, Dr. H. Malicky (ZMA); 1 \% Griechenland, Mitsu-Tal, $6 \mathrm{~km}$ S. of Monemvasia, 3-X-1980, H. Malicky (ZMA); 1 \& Peloponnisos, Kalavrita, 750 m, 26-V/16-VI-1959, H. Noack (MAK); 1 o , 1 \& Morea merid., Tayget., 1500-2000 m, 10-VII-1901, Holtz (BMNH); 1 \& Morea merid., Tayget., Wassiliki, $10 / 1500 \mathrm{~m}$, VII-1901, Holtz (BMNH).

Other material: $45 \sigma^{\circ} \sigma^{\circ}, 26 \% \propto$ from the following countries and localities: Yugoslavia: Plitvicer mts., $1 \sigma^{\circ}$ ZMA, 1 o NMW, 1 \% MAK; Montenegro, 1 ○ ZMA; Servia, 2 o* $0^{\circ}$ ZMA; Slivno, 1 o NMW; TrebovicSerajevo, 1 ○ MAK; Učka, 1 o ZMA; Albania: Voskopoj, 1 \% BMNH; Rumania: Hobita mts., $1 \sigma^{\circ}$ BMNH; Sinaia, 1 o ZMA; Bulgaria: mt. Vitosh, 1 \% BMNH; Schirokalakka, 1 o ZMA; Greece: Agrinion, 1 ơ ZMA; Andros, 13 ơ 0 , 10 ९ ९ ZMA; Diakopon, 1 \% ZMA; Euboea, $6 \sigma^{\circ} \sigma^{\circ}, 5$ ㅇํ ZMA; Gardiki Om., $1 \sigma^{\circ}$, 1 \&MNH; Katara pass, $1 \sigma^{\circ}$ MAK; Korydalos, $1 \sigma^{\circ}$ ZMA; Macedonia, 1 \& MNHNP; Oiti mts., 1 \& MAK; Olympia mts., $1 \sigma^{\circ}$ MAK; Ossa mts., 1 o ZMA; Pelion pass, 1 \& RMNH; Pilion mts., 1 \%, 1 ९ ZMA; Pindos mts., $1 \sigma^{\circ}, 1$ ९ MAK; Pisoderion, 5 ơ $0^{\circ}, 2$ ९ BMNH; Tinos, 1 ơ ZMA.

\section{Description}

Length: ơ 23-30.5 mm, ᄋ 28.5-39.5 mm. Wing length: ơ 25-32.5 mm, \& 29-33 mm. Head: Rostrum dark brown; palps dark brown to black; scape and pedicel brown, flagellar segments light brown to yellowish.

Thorax: Wing: S1 rectangular; S2 large, thinly connected along cu with $\mathrm{S} 4 ; \mathrm{M}$ cells with marginal spots; stigma red-brown, second subcostal cell whitish beyond stigma.

Abdomen: Sternite 1 brownish black. Male: tergite 9 as in $m$. maxima, sometimes larger, the lateral projections broader at the base and ending more blunt; Od obtuse with a large bulge at the posterior end (fig. 24); Id 1 as in $m$. pseudogigantea, but more pointed at apex (fig. 23); Id 2.1 somewhat shorter and thicker than in m. maxima, with 8-10 spine-like setae at the 


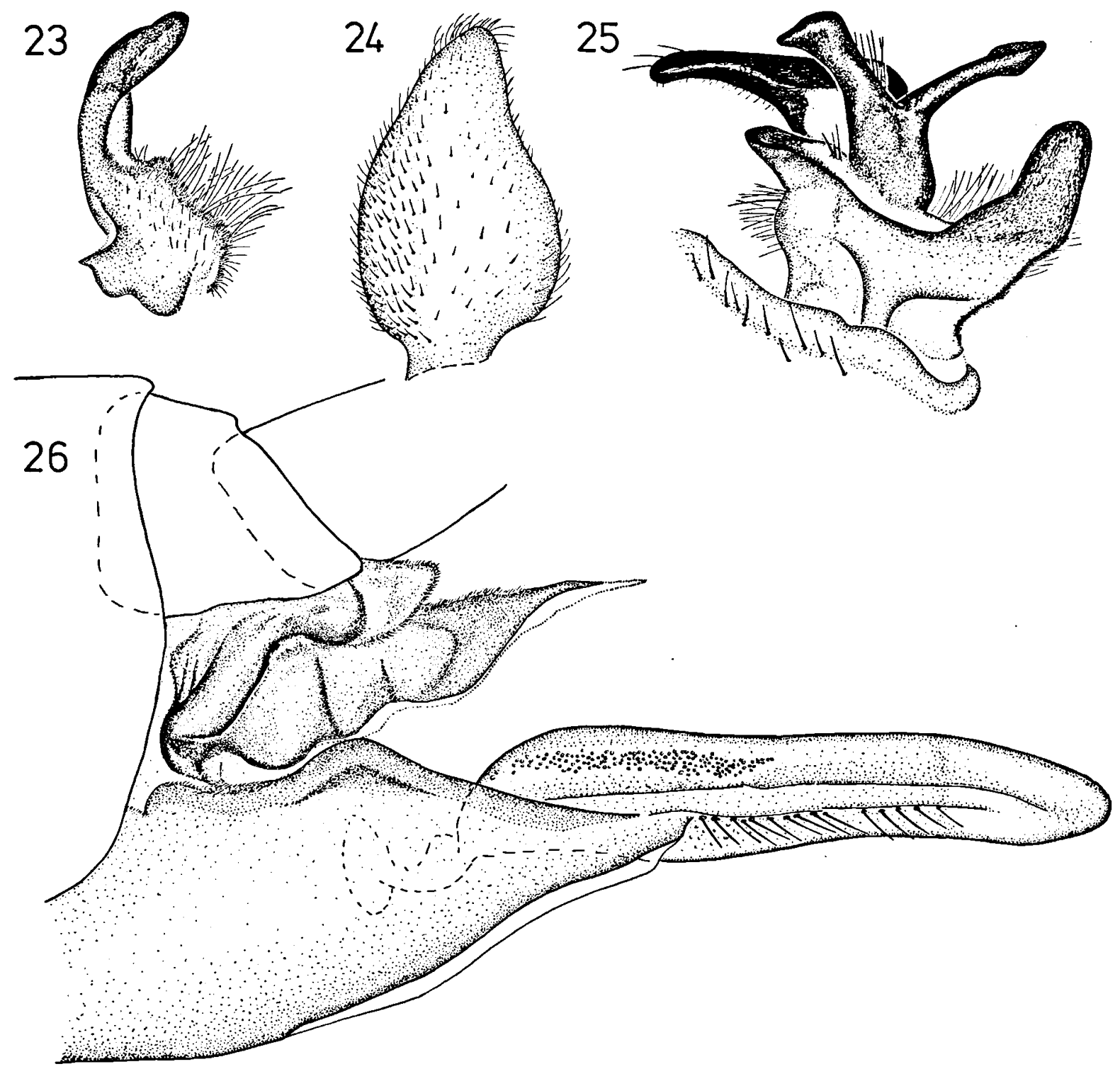

Figs. 23-26. T. (A.) maxima balcanica subspec. nov. ( $\sigma^{\circ}$ from Ucka, Yugoslavia; $Q$ paratype from Vourvoura, Greece): 23, $\sigma$ Id part 1, caudointernal view; 24, $\sigma$ Od, lateral view; 25, $\sigma$ Id, lateral view; $26, \$$ ovipositor, lateral view.

inner side above the sensory field; Id 2.2 long and slender as in m. maxima, cylindrical at base and flattened at apex like a spearhead; Id 4 with apex more angular and swollen at the base (fig. 25).

Female: membranous connection between fused valvulae and tergite 9 distinctly extending laterally and large; fused valvulae large with the apex elongate; upper margin of sternite 8 abruptly bent cranially, the part below fused valvulae broadly curved (fig. 26).

\section{Distribution (map 1)}

Central and southern Balkans, possibly USSR (Ukraine) as well (see distribution of $m$. maxima). 


\section{Biology}

Mountainous areas, likely under the same conditions as $m$. maxima. Period of flight: May till October with a peak at the end of May till the beginning of July. Recorded altitudes are up to 1700 m (Katara pass, Greece).

\section{Tipula transcaucasica Savtshenko, 1961}

This species was described by Savtshenko (1961) as a subspecies of T. maxima. Both transcaucasica and maxima are widely sympatric in the Balkans. T. transcaucasica has been given species rank for that reason. It clearly differs from $T$. maxima by the shape of tergite 9 and Id1 and Id2 (see T. maxima). The species is divided here into two subspecies.

\section{Tipula transcaucasica transcaucasica Savt- shenko, 1961, stat. nov.}

(Figs. 27-33)

Tipula maxima transcaucasica Savtshenko, 1961: 413, fig. 248.

Ref.: Theowald, 1978a: 73.

Material examined. - Type-material: Savtshenko (1961) described this species after one male holotype from the Armenian Republic, USSR, Yerevan, and $70^{\circ} \sigma^{\circ}$ and $7 \&$ from the Caucasus, Kamyshin and the Kopet Dag Khrebet. This material has not been studied.

The description and figures by Savtshenko, however, distinctly agree with the material examined (all from Iran = Persia): 1 o, Guilan, Forêt d'Assalem, 1-VII-1965, Matile (MNHNP); 1 \&, Mazanderan, Weishar, 29-VI-1965, Matile (MNHNP); $3 \sigma^{\circ} \circ, 7$ \% $\%$, near Weyser, 1150 m, 6-VIII-1968, H. M. Steiner (MAK); 1 ơ, Meshed, 30-V-1977, $1000 \mathrm{~m}$, Holzschuh \& Ressl (ZMA); $1 \sigma^{\circ}, 5 \mathrm{~km}$ E. of Novshar, $50 \mathrm{~m}$, 4-VI-1977, Holzschuh \& Ressl (ZMA); 1 \&, near Chālūs, Mazandaran, 1350 m, 7-VIII-1968, H. M. Steiner (MAK).

\section{Description}

Length: o* 22-28 mm, \& 31-36 mm. Wing length ( $\left.\sigma^{\circ}, \%\right)$ : 23-30.5 mm.

Head: Scape brown, apically dark brown to black; pedicel and flagellar segments brownish yellow; verticils up to twice the length of the flagellar segments; palps dark brown to blackish, apically lighter.

Thorax: Pleurae yellow to yellowish brown; wing with S1 and S2 far apart, divided by a broad triangular white spot; the apical end of R3 cell white; S4 small; S5 small; the posterior half of the discoid cell brown; $M$ cell almost entirely vaguely coloured.

Abdomen: Male: tergite 9 with compact medial projections, with narrower fissure than in T. maxima (figs. 27, 28); Od as in fig. 29 with slender tip; Id1 slender, tooth-like with a concave and sclerotized apex, at the base more swollen and hirsute (figs. 30, 31); Id2.1 rounded towards the acute tip, at the inner side just above the sensory field with 8-10 setae; Id2. 2 large, the posterior margin crest-like (fig. 30 ); Id3 as in T. maxima but with no hairs on the apex.

Female: the membranous connection between sternite 8 and tergite 9 less vaulted sidewards than in $T$. maxima; the upper margin of sternite 8 evenly curved with a broad, slightly sclerotized margin (fig. 33); furca narrow at the posterior end (fig. 32).

Distribution (map 2)

Caucasus mountains between the Black and Caspian Seas, Kopet Dag Khrebet in northern Iran and southern USSR. Also recorded from Kamyshin (Volgogradskaja Obl.).

\section{Biology}

Ecology likely as in $T$. maxima, near running water. Period of flight from May till October. Recorded altitudes are up to $1350 \mathrm{~m}$ (Chālūs).

\section{Tipula transcaucasica latifurca subspec. nov.}

(Figs. 34-36)

Material examined. - Holotype: $\sigma$ from Bulgaria, labeled: "Bulgarien, Katundre $(15 \mathrm{~km} \mathrm{~N}$. Malko Turnovo), $200 \mathrm{~m}, 15 / 16-\mathrm{VI}-1980,42^{\circ} 04^{\prime} \mathrm{N} 27^{\circ} 27^{\prime} \mathrm{E}$, Dr. Hans Malicky, BG3"' (ZMA).

Paratypes (all from Bulgaria): 1 ९, $11 \mathrm{~km} \mathrm{~N}$. of Malko 

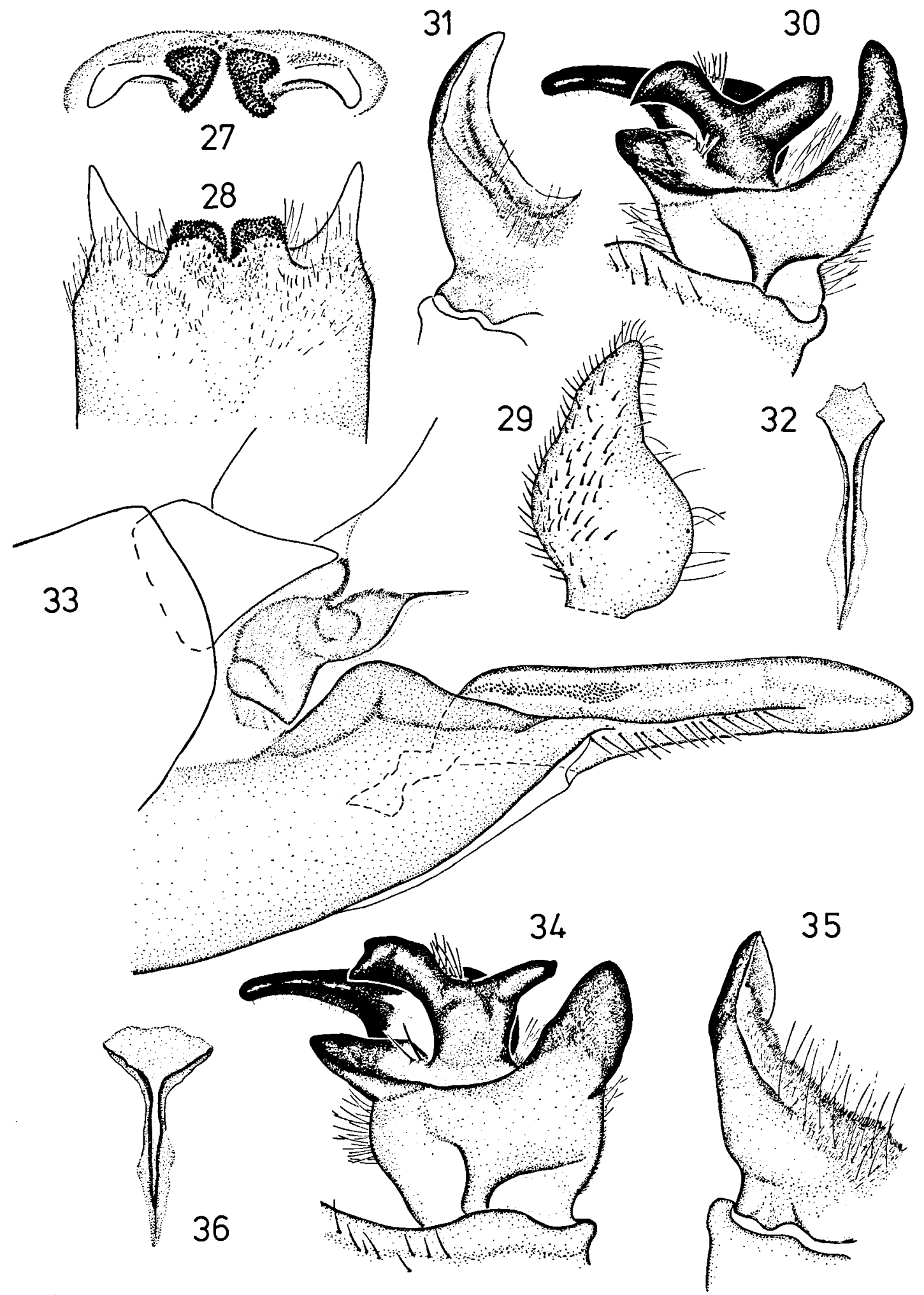

Figs. 27-33. T.(A.) transcaucasica transcaucasica Savtshenko, 1961 stat. nov. ( $\sigma^{\circ}, \odot$ from Weyser, Iran): 27, $\sigma^{\circ} \mathrm{T} 9$, caudal view; 28, o T9, dorsal view; 29, ơ Od, lateral view; 30, o Id, lateral view; 31, o Id part 1, caudointernal view; 32, furca, dorsal view; 33 , $\$$ ovipositor, lateral view.

Figs. 34-36. T. (A.) transcaucasica latifurca subspec. nov. ( $\sigma^{\circ}$ from Ikaria, Greece): 34, $O^{\circ}$ Id, lateral view; 35, O' Id part 1, caudointernal view; 36 , \& furca, dorsal view. 
Turnovo, $250 \mathrm{~m}, 42^{\circ} 03^{\prime} \mathrm{N} 27^{\circ} 28^{\prime} \mathrm{E}, 16-\mathrm{VI}-1980$, Dr. Hans Malicky, BG8 (ZMA); $10^{\circ}, 1$ \%, (Abw. B. Brschljan), W. of Mladesko, $200 \mathrm{~m}, 16 / 17-\mathrm{VI}-1980,42^{\circ} 10^{\prime} \mathrm{N}$ $27^{\circ} 23^{\prime} \mathrm{E}$, Dr. Hans Malicky, BG9 + 10 (ZMA); $1 \sigma^{\prime}$, Veleka, $2 \mathrm{~km}$ unterhalb Katschul, $42^{\circ} 01^{\prime} \mathrm{N} 27^{\circ} 40^{\prime} \mathrm{E}$, 17-VI-1980, 80 m, Dr. Hans Malicky, BG15 (ZMA); 1 $0^{\circ}$, S.W. of Stoipovo, $250 \mathrm{~m}, 18-\mathrm{VI}-1980,42^{\circ} 00^{\prime} \mathrm{N}$ $27^{\circ} 32^{\prime} \mathrm{E}$, Dr. Hans Malicky, BG18 (ZMA). All typematerial is preserved in alcohol (ZMA).

Other material: $35 \sigma^{\circ} \sigma^{\circ}, 23 \% \&$ from the following countries and localities: Yugoslavia: Bosna, 1 \&MA; Macedonia, 1 \& BMNH; Baba mts., $3 \sigma^{\circ} \sigma^{\circ}, 1$ \% RMNH; Lake Ohrid, $1 \sigma^{\circ, 1}$ \& RMNH; Greece: Oiti mts., 4 o $\sigma^{\circ}$ MAK; Portaria, 1 \& ZMA; Euboea, $4 \sigma^{\circ} \sigma^{\circ}$ ZMA; Ikária, 1 \& ZMA; Samos, 4 \% 0 ZMA; Thásos, 3 ơ 0,2 \& \& ZMA; Turkey: Akşehir, 1 o MAK, 1 \& ZMA; Çay, 2 ơ , 4 \& \& ZMA; Maçka, 1 \&MA; Tatvan, 3 \% $\sigma^{\circ} \mathrm{MAK}, 2 \sigma^{\circ}$ ZMA; Ercis, 3 \% $\sigma, 1 \%$ MAK; Van Gölü, 1 \& MAK; Ziganadag, 1 \% MAK; Rize, $10^{\circ}, 2$ \& $ᄋ$ MAK; Mus, 1 ○ ZMA; Pozanti, 1 ㅇ ZMA; Tekir, 2 \& \& ZMA; Lebanon: Becharré, 1 \% , 1 \% MAK, 1 \%, 1 \& NMW.

\section{Description}

Length: $\sigma$ $20-30 \mathrm{~mm}$, \& $29-39 \mathrm{~mm}$. Wing length $\left(\sigma^{\circ}\right.$, \&): $23-33 \mathrm{~mm}$.

T. $t$. latifurca is almost identical to the nominal subspecies, differing in the length of the verticils of the flagellar segments of the antennae, which are about 1.5 times the length of the flagellar segments; the S1 and S2 of the wing are separated by a more trapezoid whitish band; S4 is larger; $\mathbf{M}$ cells are less vaguely coloured.

Male: tergite 9 with the shape of the medial projections sometimes more in between maxima and transcaucasica; Id1 broader than in $t$. transcaucasica, the inner side more swollen towards the tip (fig. 35). Id2.1 less rounded and not evenly curved at the apex, but with an irregular bulb; Id2.2 more slender (fig. 34).

Female: ovipositor as in $t$. transcaucasica (tig. 33 ), but the apex of the furca about three times as broad (fig. 36).

\section{Distribution (map 2)}

Distributed in the southern Balkans, Turkey and Lebanon. Apparently without overlap with the nominal subspecies.

\section{Biology}

Period of flight from May until July. Recorded altitudes are $1400 \mathrm{~m}$ (Lebanon), $1900 \mathrm{~m}$ (Turkey), $800 \mathrm{~m}$ (Greece) and $1300 \mathrm{~m}$ (Yugoslavia).

\section{Tipula libanica spec. nov.}

(Figs. 37-42)

Material examined. - Type-material: Holotype: $\sigma^{\circ}$ from Lebanon, labeled: "Liban, Jabal el Barouk, Nahr ed Damour, 18-IX-1980, St. 25 PL, A. Dia leg." (in the University of Lebanon, Hadeth, Beyrouth).

Paratypes: $1 \propto \circ, 1$ \&, Lebanon, Nabaa Aziti, Djezzine, 22-VI-1981, A. Dia leg. (ZMA). All types are preserved in alcohol.

\section{Description}

Length: $\sigma^{*} 25-30 \mathrm{~mm}, \$ 40 \mathrm{~mm}$. Wing length: $\left(\sigma^{\circ}\right.$, Q ): $24-29 \mathrm{~mm}$.

Head: Antennae short, about as long as the total length of the head; scape and pedicel brown; flagellar segments light brown; scape apically darkened.

Thorax: Prescutum with four brown longitudinal stripes without darkened borders. Wing: M1-4 with small spots at wing margin; S4 larger than in $t$. transcaucasica; S5 small; posterior half of discoid cell brown.

Abdomen: Male: tergite 9 as in figs. 37 and 38 , the lateral projections somewhat broader at the base than in $t$. transcaucasica; Od invaginated at posterior margin (fig. 39); the inner side of the Id 1 concave as in $m$. balcanica, but broader at the base and narrowing at the apex, with a distinct hirsute swelling at the base of Id2 (fig. 41); Id2.1 laterally more flattened, shorter and broader than in $t$. transcaucasica, with eight spine-like setae at the inner side above the sensory field; Id2.2 cylindrical and elongate into a wriggling apex (fig. 40).

Female: ovipositor as in fig. 42, the membranous connection between tergite 9 and sternite 8 stronger vaulting sidewards over the hirsute upper margin of sternite 8 than in $m$. maxima or t. transcaucasica. 


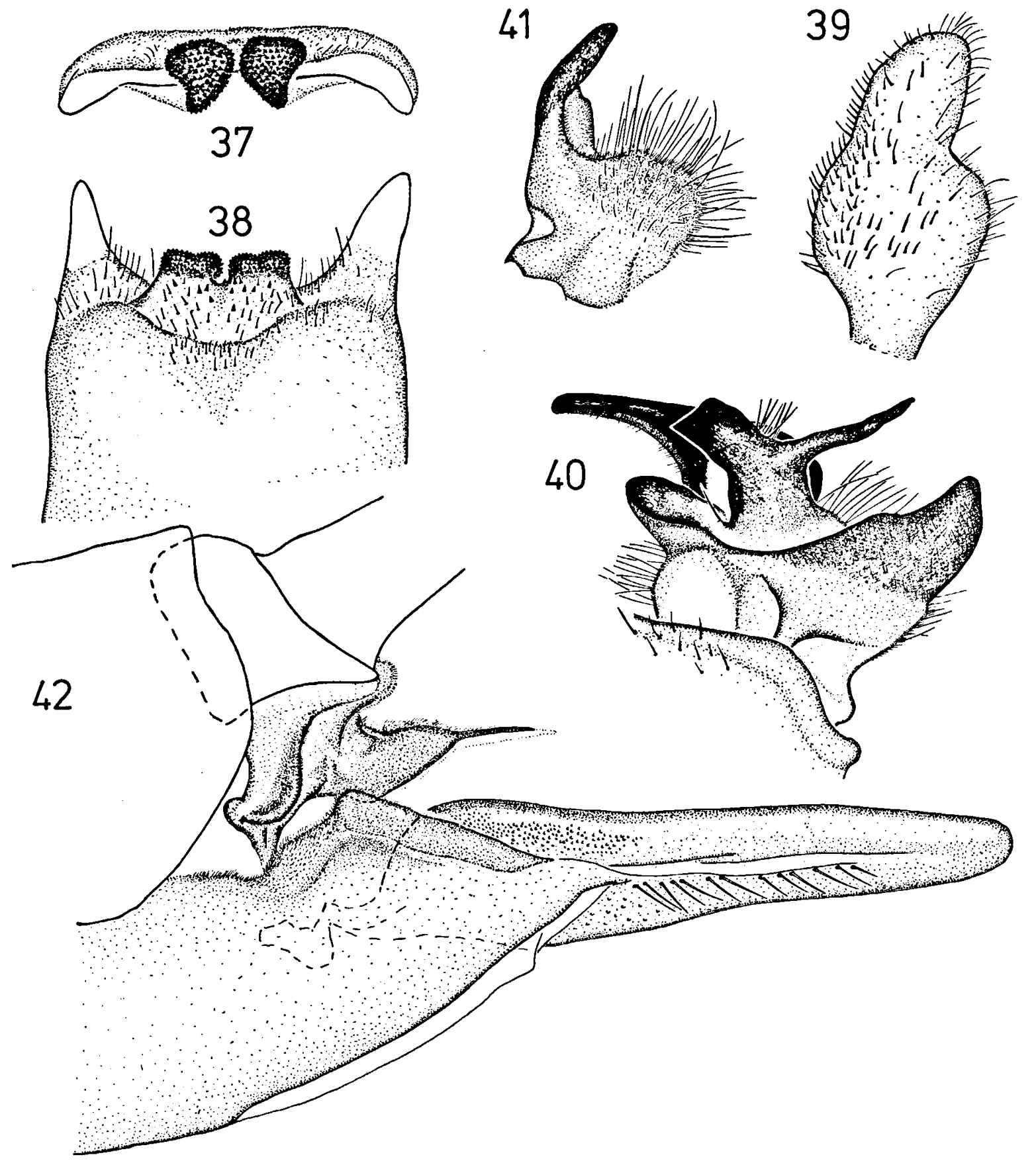

Figs. 37-42. T. (A.) libanica spec. nov. ( $\sigma^{*}, \bigcirc$ paratypes from Nabaa Aaziti, Lebanon): 37, $\sigma^{\circ}$ T9, caudal view; 38, $\sigma^{\circ}$ T9, dorsal view; 39, $\sigma^{\circ}$ Od, lateral view; 40 , $\sigma^{\circ}$ Id, lateral view; 41, $\sigma^{\circ}$ Id part 1, caudointernal view; 42 , $९$ ovipositor, lateral view.

\section{Distribution (map 1)}

Known from Lebanon only.

\section{Biology}

Near streams in mountainous areas. Period of flight from June up to September inclusive. 


\section{Remark}

More material of either libanica or $t$. latifurca was collected by A. Dia (University of Lebanon, Hadeth, Beyrouth) but was not available for the present study.

\section{Tipula (Acutipula) corsica subgroup}

This second section includes four closely related, more or less endemic species from the circum-Mediterranian region. The characters defining this subgroup are: Id1 present as a sclerotized ridge; Id2.1 large and robust; Id2.2 very small; apex of the intromittent organ tridental (fig, 7).

\section{Tipula corsica Pierre, 1921}

(Figs. 2, 43-47)

Refs.: Pierre, 1921: 47-48, fig. 1; Mannheims, 1952: 103 (as synonym of maxima); Savtshenko, 1961: 411.

Material examined. - Type-material: Holotype: $\$$, from Corsica, labeled: "Forêt de Valdoniello, 25-VI, G. Bernard" (MNHNP).

Other material: $20^{\circ}, 5$ \& 5 from the following localities on Corsica: Sartène, Calvi, Asco and Vizzavona.

\section{Description}

Length: $\sigma^{\circ} 20-22.5 \mathrm{~mm}$, ᄋ $28-31 \mathrm{~mm}$. Wing length $\left(\sigma^{\circ}, \$\right)$ : $24.5-26.5 \mathrm{~mm}$.

Head: Antennae brown, flagellar segments darker than the scape, especially at the base; palpi dark brown to blackish.

Thorax: Wings: S2 cone-shaped, narrowing in $M$ cell and broadening towards cu vein; $R 3$ cell entirely brown; $R 4+5$ cell only brown at base near discoid cell, the distal $2 / 3$ part white to wing margin; discoid cell white, with narrow brown lines along the veins only; M1-3 cells for more than the half coloured brown; S4 largely drawn out to discoid cell; S5 elongate along cu to S1 and S2 (fig. 2).

Abdomen: Male: tergite 9 with medial projections somewhat rounded (figs. 43,44); Od as in fig. 45 ; Id1 present as a narrow ridge; Id2.1 pointed and broadly flattened; Id2.2 just present as a small thorn-like projection (fig. 46).

Female: ovipositor as in fig. 47, the membranous connection between sternite 9 and tergite 9 slightly extended sidewards.

\section{Distribution (map 3)}

Endemic to Corsica.

\section{Biology}

Period of flight from April to July. Recorded altitudes up to $1700 \mathrm{~m}$.

8. Tipula rifensis Theowald \& Oosterbroek, 1980

(Figs. 48-52)

Ref.: Theowald \& Oosterbroek, 1980: 183, fig. 3.

Material examined. - Type-material: Holotype: $\sigma^{\circ}$ from Morocco, labeled: "Targuist, Rif, VI-1930, exp. C. Bolivar" (MAK).

Other material: 1 \% from Morocco, Tidiguin, $90 \mathrm{~km}$ E. of Ouezzane, $2350 \mathrm{~m}, 18-\mathrm{VI}-1951$, leg. J. Dorgelo (ZMA).

\section{Description}

Length: $\sigma^{\circ}$ ca. $23 \mathrm{~mm}$ (holotype dissected), $Q$ : $31 \mathrm{~mm}$. Wing length $\left(\sigma^{\circ}, \%\right): 24 \mathrm{~mm}$.

Head: Antennae light brown: flagellar segments darker at the base.

Thorax: Legs brown to dark brown; prescutum with four brown stripes, with broad grey stripes in between; wing: S1 and S2 separated by a narrow parallel crossline; R3 cell entirely brown; $R 4+5$ cell almost entirely brown with a brown marginal spot; stigma reddish brown; $M$ cells almost entirely vaguely brown.

Abdomen: Male: tergite 9 with broadly rounded medial projections (figs. 48, 49); Od as in fig. 50; Id1 as in T. corsica; Id2-1 large and rounded at the apex; Id2-2 small and pointed, slightly larger than in $T$. corsica; Id4 regularly pointed and dorsally flattened, at the base of Id2.1 about seven hairs (fig. 51). 


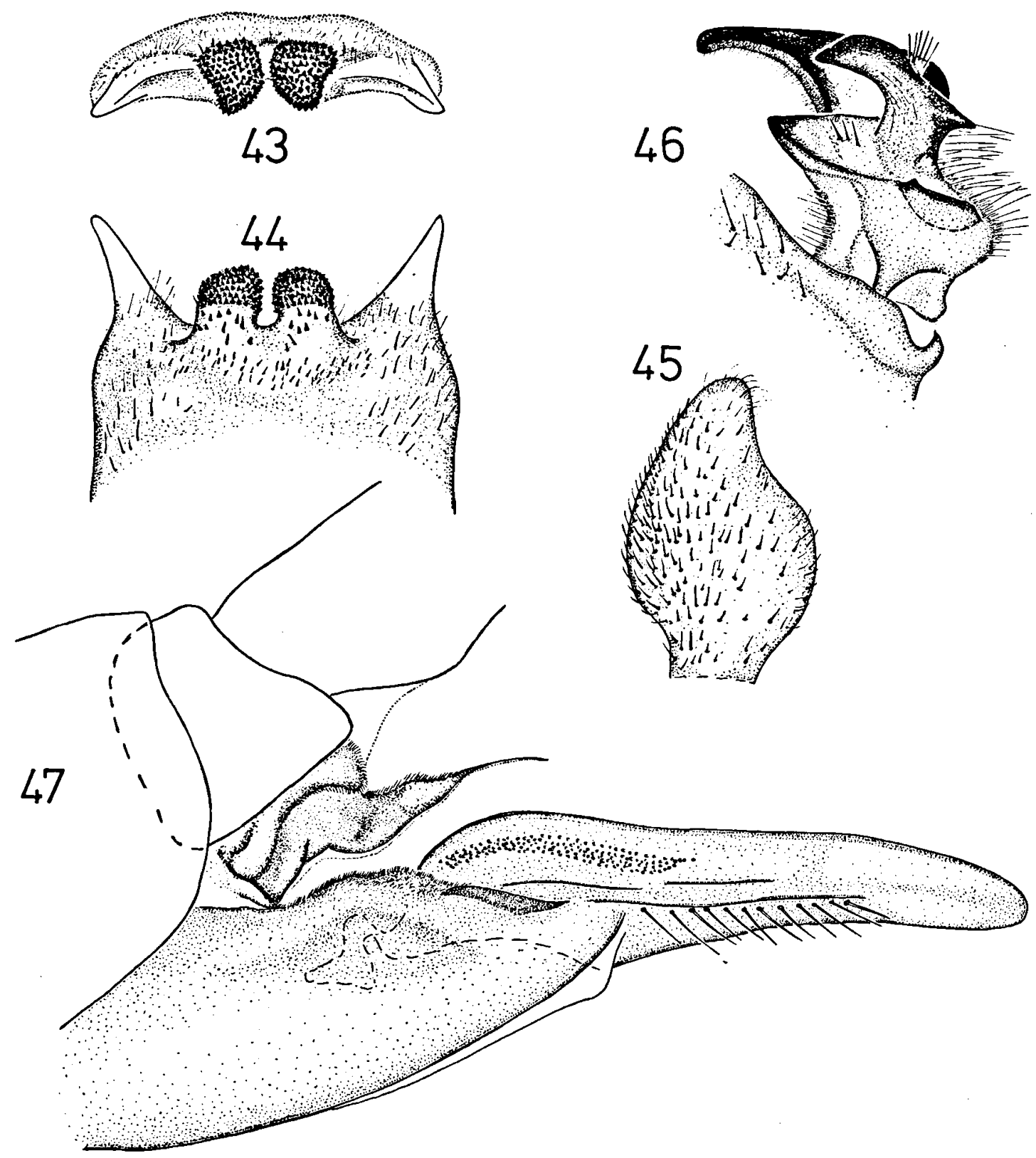

Figs. 43-47. T. (A.) corsica Pierre, 1921 ( $\sigma^{\circ}, \bigcirc$ from Asco, Corsica): 43, $\sigma^{\circ} \mathrm{T} 9$, caudal view; 44, $\sigma^{\circ} \mathrm{T} 9$, dorsal view; 45, ơ Od, lateral view; 46, ơ Id, lateral view; 47 , $९$ ovipositor, lateral view.

Female: ovipositor as in fig. 52, the upper Biology margin of sternite 8 hirsute.

Period of flight: June. Recorded altitude 2350

\section{Distribution (map 3)}

Apparently endemic to Morocco (Rif mountains). m.

\section{Discussion}

From the Rif mountains only $1 \sigma^{\circ}$ and $1 \%$, belonging to the maxima group, are known. The 


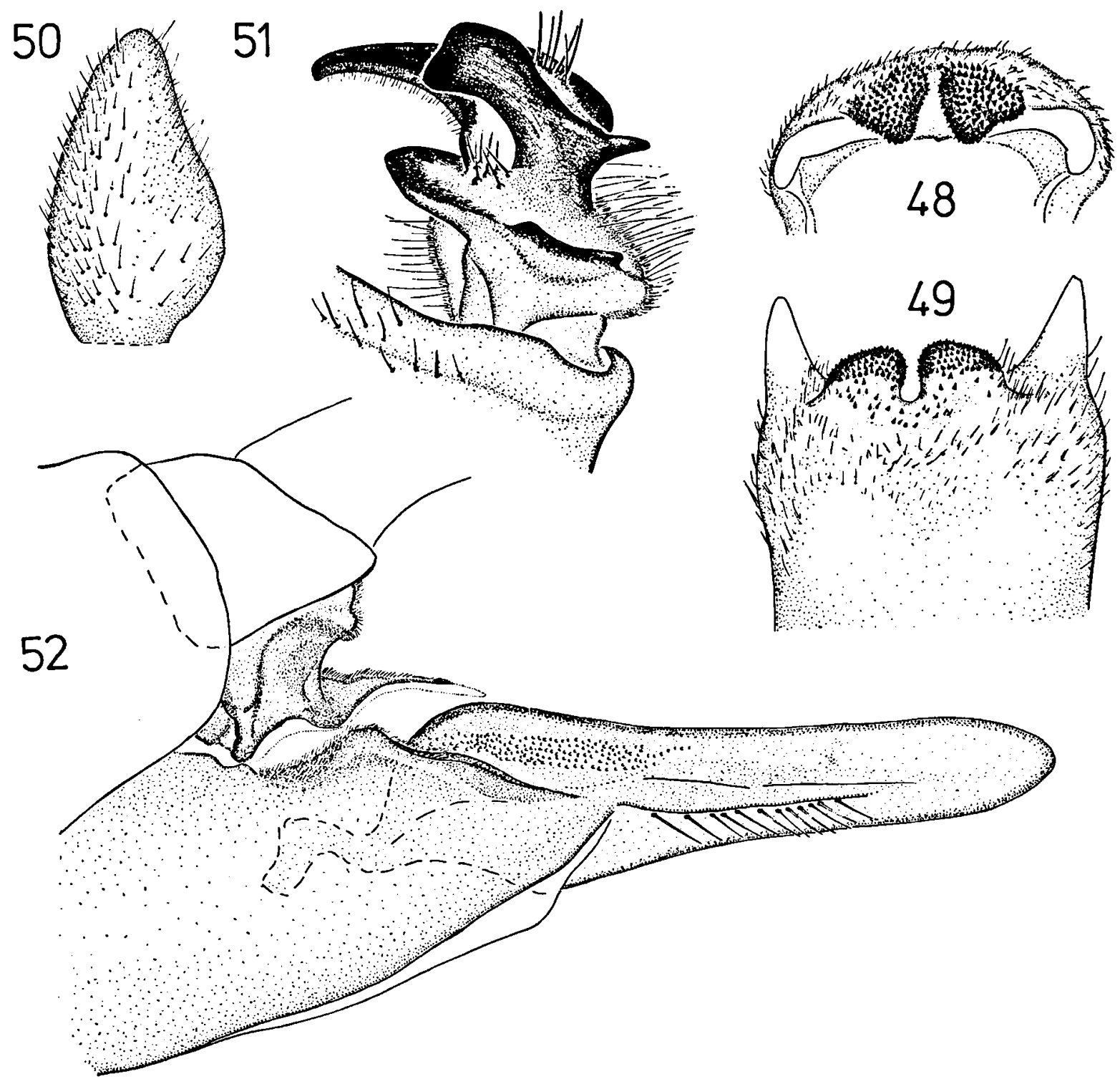

Figs. 48-52. T. (A.) rifensis Theowald \& Oosterbroek, 1980 ( $\sigma$ holotype from Targuist, Morocco; $\$$ from Tidiguin,

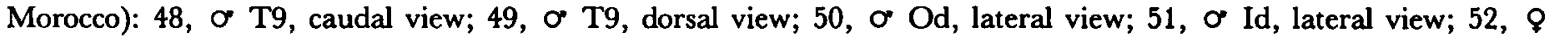
ovipositor, lateral view.

female is assigned to rifensis according to the wing pattern, the ventral eye distance and the colouration of head and thorax.

\section{Tipula cretensis spec. nov.}

(Figs. 53-56)

Material examined. - Type-material: Holotype: $\sigma$ from Crete, labeled: “Griechenland, Kreta, Fassastal W.
Chliaro, $290 \mathrm{~m}, 35^{\circ} 24^{\prime} \mathrm{N} 23^{\circ} 53^{\prime} \mathrm{E}, 18 / 20-\mathrm{V}-1977$, Dr. Hans Malicky leg." (ZMA).

Paratypes: $20^{\circ} \sigma^{\circ}$, Griechenland, Kreta, Perivolia, $450 \mathrm{~m}$, $16-V-1979,35^{\circ} 22^{\prime} N 23^{\circ} 37^{\prime}$ E. Dr. H. Malicky, K. 613 (ZMA); $1 \circ^{\circ}$, Griechenland, Kreta, 400 m, Kakopetros, 13-V-1979, $35^{\circ} 24^{\prime} \mathrm{N} 23^{\circ} 45^{\prime} \mathrm{E}$, Dr. H. Malicky, K611 (ZMA). All type-material is preserved in alcohol.

\section{Description}

Length: ơ 25-27 $\mathrm{mm}$, \& unknown. Wing length: $\sigma^{\circ}$ 27-30 $\mathrm{mm}$. 
Head: Scape and pedicel brown; flagellar segments more yellowish; verticils somewhat longer than the segments; palps brown at the base, at the apex light brown to yellowish.

Thorax: Prescutum yellow-brown, the four longitudinal stripes not bordered, the two medial stripes almost fused into one; wing: S2 large and thinly connected along cu with S4; R3 entirely brown; $R 4+5$ brown at the base, halfway with white spots, the apical part white; S4 small; S5 almost drawn out to S1 and S2. Abdomen: Male: tergite 9 somewhat in between $T$. corsica and $T$. rifensis, the medial projections rounded and almost ovally shaped (figs. 53, 54); Od oblong and narrow with hirsute tip (fig. 55); Id1 present as a small ridge, the inner side more concave than in the other species of this subgroup (fig. 56); Id2.1 broad and laterally flattened, with tapering apex; Id2.2 small, the base of Id2 larger than in $T$. corsica, $T$. rifen-
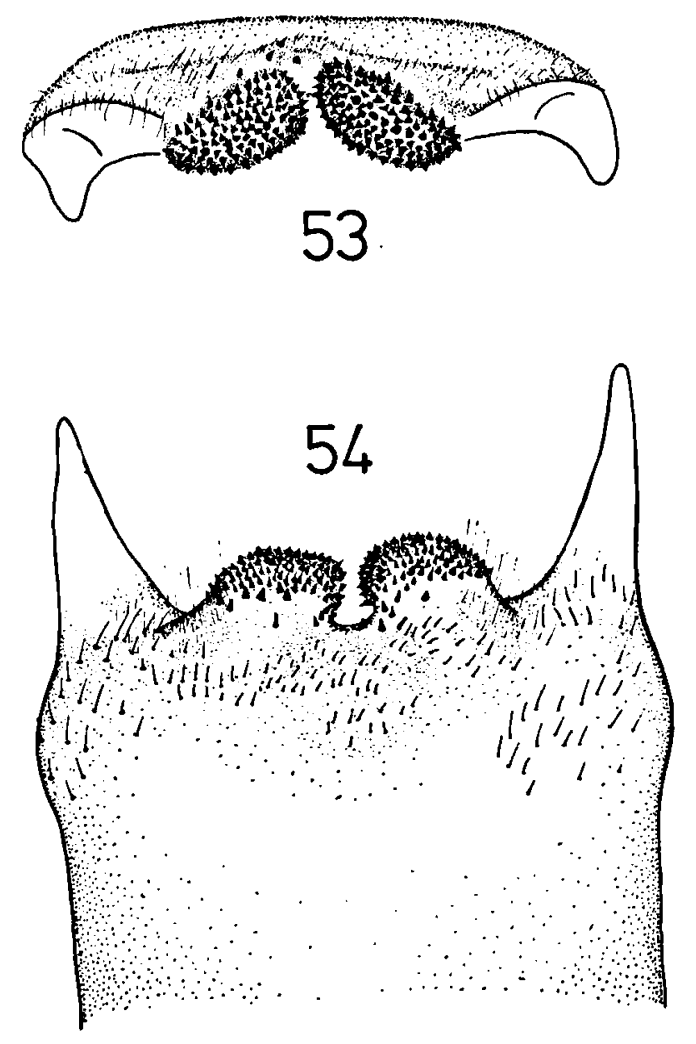

sis or T. macra. The apical half of Id3 more robust than in the other species of the corsica and maxima subgroups; Id4 dorsally flattened with a regular row of setae (fig. 56).

Female unknown.

Distribution (map 3)

Endemic to Crete.

Biology

Period of flight from May until July. Recorded altitudes are up to $450 \mathrm{~m}$.

10. Tipula macra Savtshenko, 1961

(Figs. 57-61)

Refs.: Savtshenko, 1961: 414, fig. 250; Mannheims, 1964: 4, fig. 3; Theowald, 1978a: 73.

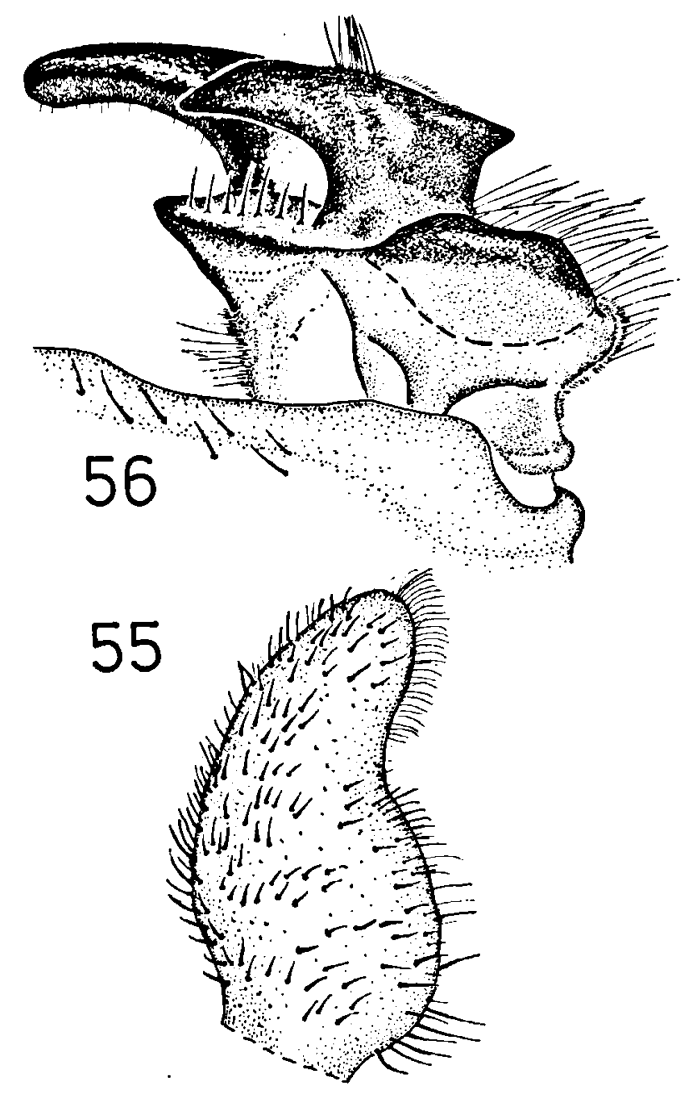

Figs. 53-56. T. (A.) cretensis spec. nov. ( $\sigma^{\circ}$ paratype from Perivolia, Crete): 53, $\sigma^{\circ} \mathrm{T} 9$, caudal view; 54, $\sigma^{\circ} \mathrm{T} 9$, dorsal view; 55 , o Od, lateral view; 56 , o Id, lateral view. 
Material examined. - Type-material: This species was described by Savtshenko (1961) after 10 from Azerbajdzjan, Leriks region: Mistan, 30-V-1959, Zaitsjev leg.

The author's knowledge is based upon this description and figure, and on specimens identified by Savtshenko: 1 ๙ , Polur, S. Demarwand, 2200 m, 22-VII-1977 (ZMA); $20^{\circ}, 1$ \&, Nachitshaven Arit, U.S.S.R., near Nasyrwaz, 24-VI-1967, Savtshenko leg. (MAK).

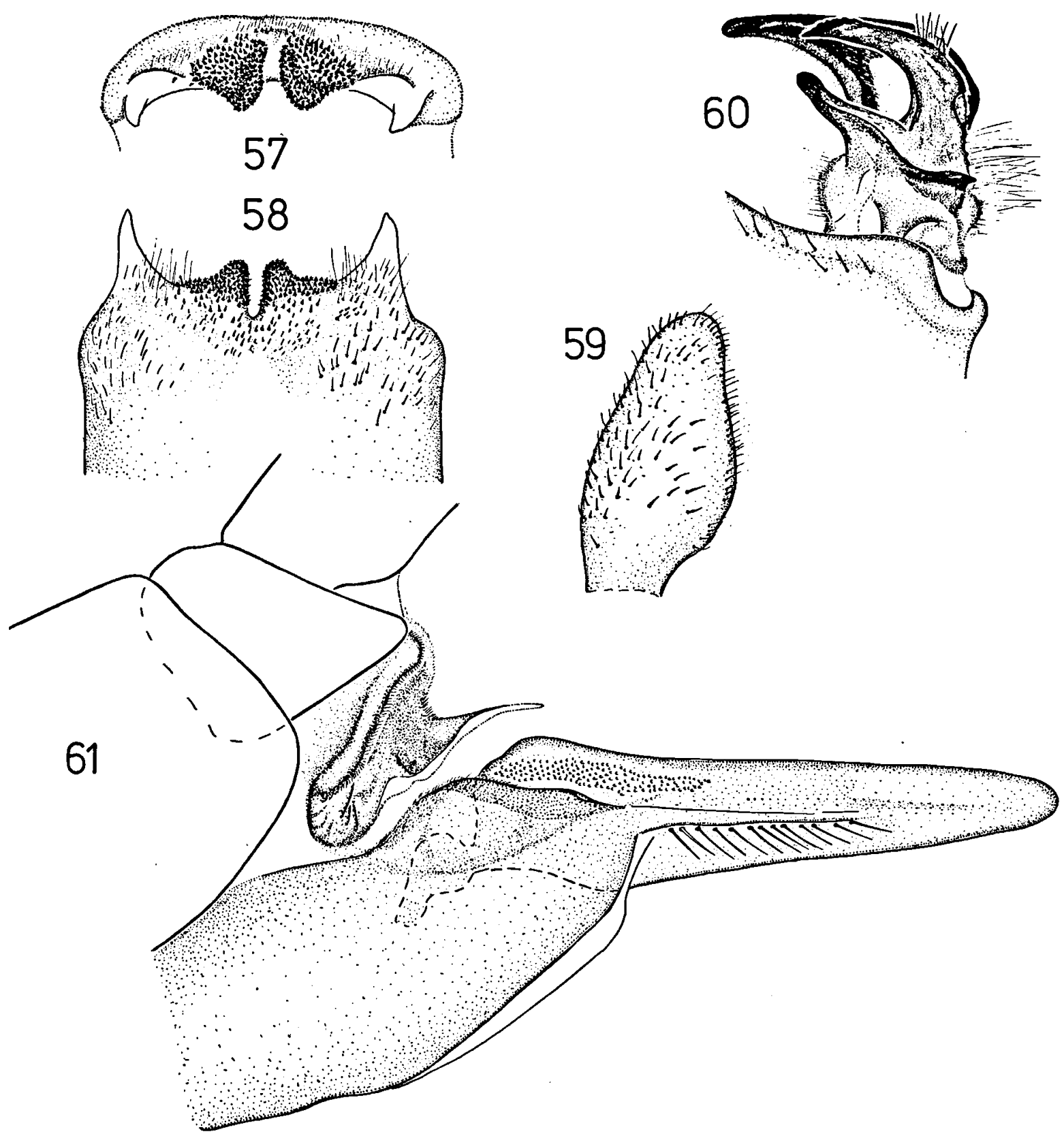

\section{Description}

Length: O* 23-24 mm, \& $23 \mathrm{~mm}$. Wing length $\left(O^{*}\right.$, Q ): $22.5-26.5 \mathrm{~mm}$.

Head: Scape and pedicel dark brown; flagellar segments light brown to brown; verticils somewhat longer than the segments; palps dark

Figs. 57-61. T. (A.) macra Savtshenko, 1961 ( ${ }^{\circ}, \propto$ from Nachitshaven Arit, U.S.S.R.): 57, $\sigma^{\circ}$ T9, caudal view; 58, $\sigma^{\circ}$ $\mathrm{T} 9$, dorsal view; $59, \sigma^{\circ}$ Od, lateral view; 60 , $\sigma^{\circ} \mathrm{Id}$, lateral view; 61 , 9 ovipositor, lateral view. 
brown at the base, the apex light brown to yellowish; eyes broadly separated ventrally, distance 3-3.6 times the diameter of the scape. Thorax: Wing: S2 cone-like, slightly indented in the $\mathrm{M}$ cell, but not as far as in $T$. corsica; base of R2 brighter beyond stigma; R3 brown near discoid cell, more distally bright with brown spot at wing margin.

Abdomen: Male: tergite 9 with short lateral projections, the medial projections are more narrowed towards the middle (fig. 58); Od with a bluntly rounded tip (fig. 59); Id1 present as a small ridge (fig. 60); Id2.1 more slender than in $T$. corsica, elongate and sharply pointed; Id2.2 with a sharp, short pin just above the sensory field; Id4 slender, dorsally flattened with a rounded tip slightly bending upwards (fig. 60).

Female: ovipositor as in fig. 61; the upper margin of sternite 8 evenly curved, the anterior part hirsute; apex of fused valvulae short.

\section{Distribution (map 3)}

Known from the eastern Caucasus and the adjacent regions of northern Iran.

\section{Biology}

Period of flight from the end of May until September. Recorded altitude $2200 \mathrm{~m}$.

\section{Tipula (Acutipula) doriae subgroup}

This third section includes three species with only a few but distinct characters in common. The apex of the intromittent organ is bispicate with two extra hooklets (fig. 8); Id2 consists of only one projection with the sensory field situated at the dorsocaudal side of the more or less reduced base; the shape of the hypovalva is lanceolate and the apex of the fused valvulae narrow.

\section{Tipula doriae Pierre, 1926}

(Figs. 3, 62-66)

Refs.: Pierre, 1926: 13-14, figs. 83-87; Mannheims, 1952: 103, fig. 55; Mannheims, 1953: 3; Mannheims \&
Theowald, 1959: 18; Savtshenko, 1961: 415-416, fig. 252; Theowald, 1978b: 365 .

Material examined. - Type-material: $T$. doriae was described by Pierre after 1 o' from Italy, Giglio, IX-1897, Doria leg. This type was not present in the Pierre collection in the Paris museum, probably it is preserved in Genua. The author's knowledge is based on the description of Pierre and on the figures given by Mannheims and Savtshenko.

Other material: $41 \sigma^{\circ}, 16 \&$ from France: Corsica (8 localities), Italy: Sardinia (11 localities) and Algeria (1 locality).

\section{Description}

Length: $\sigma$ $19.5-33 \mathrm{~mm}$, $९$ 27-37 $\mathrm{mm}$. Wing length $\left(\sigma^{\circ}, \%\right)$ : $19-30 \mathrm{~mm}$.

Head: Antennae brown; flagellar segments darker than the scape and pedicel; ventral distance between the eyes about one time the diameter of the scape.

Thorax: Wing: the base of cell R2 beyond the stigma lightly coloured; R4 +5 near discoid cell brown, the apical half of $R 4+5$ white, sometimes with a small brown spot at wing margin; discoid cell white with broad brown margins along the veins; M1-3 almost entirely brownish; in M1 a clear white spot near $\mathrm{m} 1$ at wing margin; S5 large (fig. 3).

Abdomen: Male: tergite 9 with long lateral projections, the medial projections short, narrow and shaft-like (figs. 62, 63); Od strongly invaginated at posterior side (fig. 64); Id1 broad and flattened; at apex irregular and cranially with three setae; Id2 spatulate, rounded at top with 6 spine-like setae at inner side, Id2.2 absent; sensory field almost at posterior base of Id2; Id4 broad at the base, at flattened dorsal side somewhat undulate, the apex rounded (fig. 65).

Female: ovipositor as in fig. 66, with a distinct white spot at the base of the hypovalva; the upper margin of sternite 8 folded inwards; the apex of the fused valvulae elongate.

\section{Distribution (map 4)}

Corsica, Sardinia, Giglio. Only one male is known from Algeria, Fort National, 2-XI-1892, Rev. E. A. Eaton leg. (BMNH). 


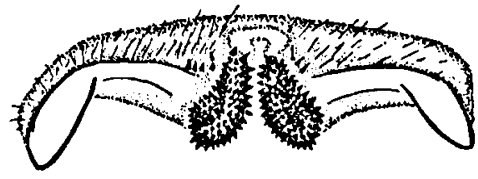

62
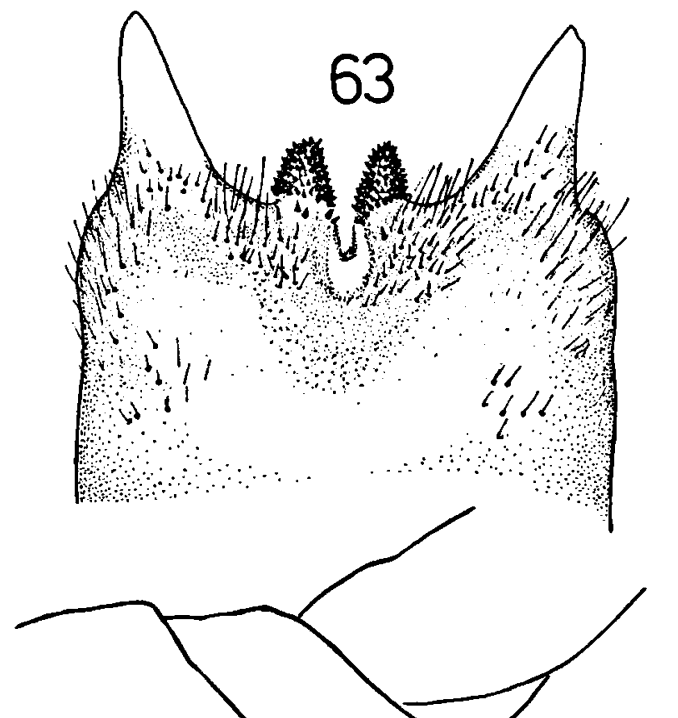

66
64

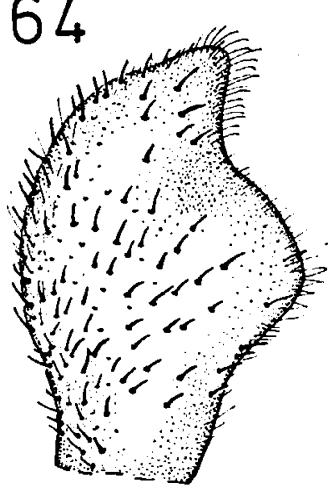

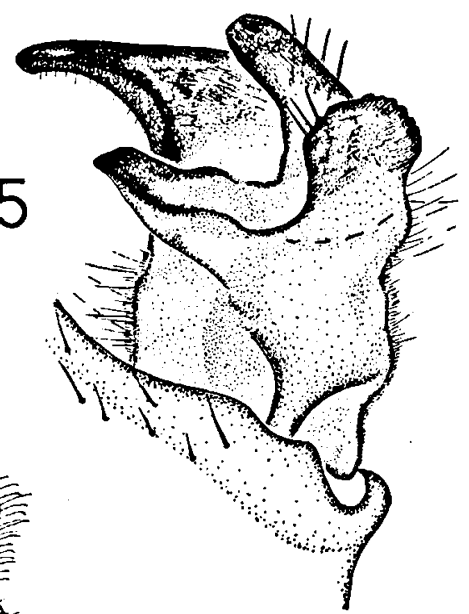

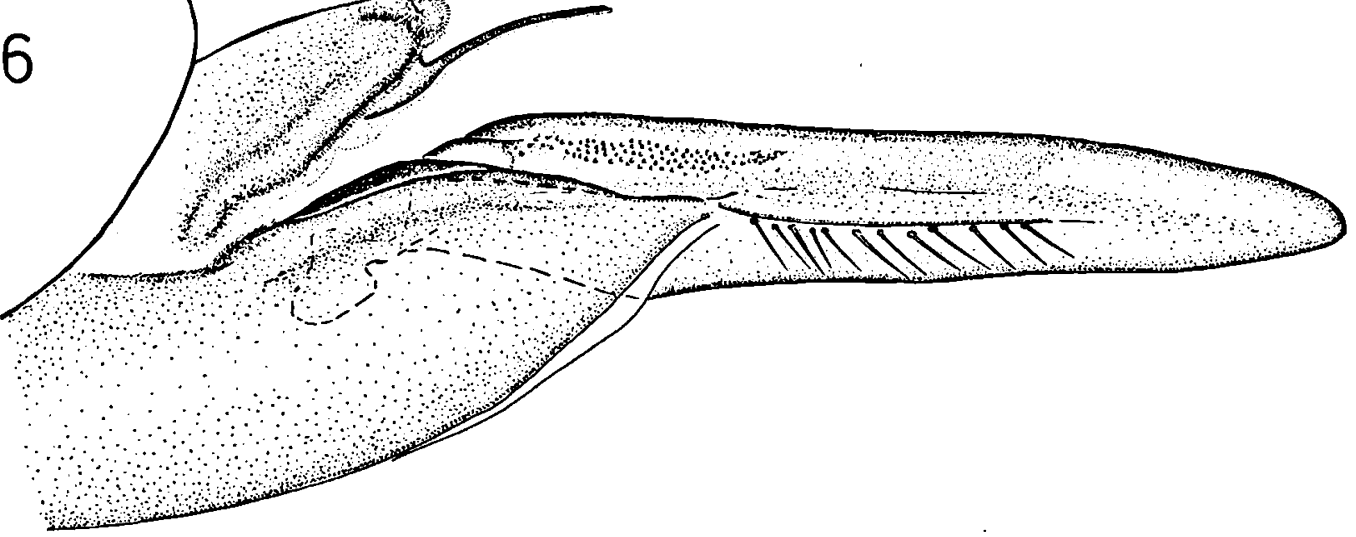

Figs. 62-66. T. (A.) doriae Pierre, 1926 ( $\circ$ from Tavera, Corsica; $९$ from Mti. Gennargentu, Sardinia): 62, $0^{\circ}$ T9, caudal view; $63, \sigma \mathrm{T} 9$, dorsal view; $64, \sigma^{\circ}$ Od, lateral view; 65 , $\sigma^{\circ} \mathrm{Id}$, lateral view; 66 , $९$ ovipositor, lateral view.

Biology

Period of flight from June until November. Recorded altitude $1000 \mathrm{~m}$. (Sardinia).

12. Tipula cypriensis spec. nov.

(Figs. 67-70)

Material examined. - Holotype: $\sigma$ from Cyprus, labeled: "Cyprus, miss D. M. A. Bate 1903-64" (BMNH).

\section{Description}

Length: $\sigma^{\prime} 20 \mathrm{~mm}$, $Q$ unknown. Wing length $\left(O^{\circ}\right): 23 \mathrm{~mm}$.

Head: Rostrum dark brown to rusty brown; scape brown; pedicel and flagellar segments light brown to yellow-grey; verticils about twice the length of the segments or more; palpi brown, the apical parts of the palpal segments lighter; nasus fairly elongate. 

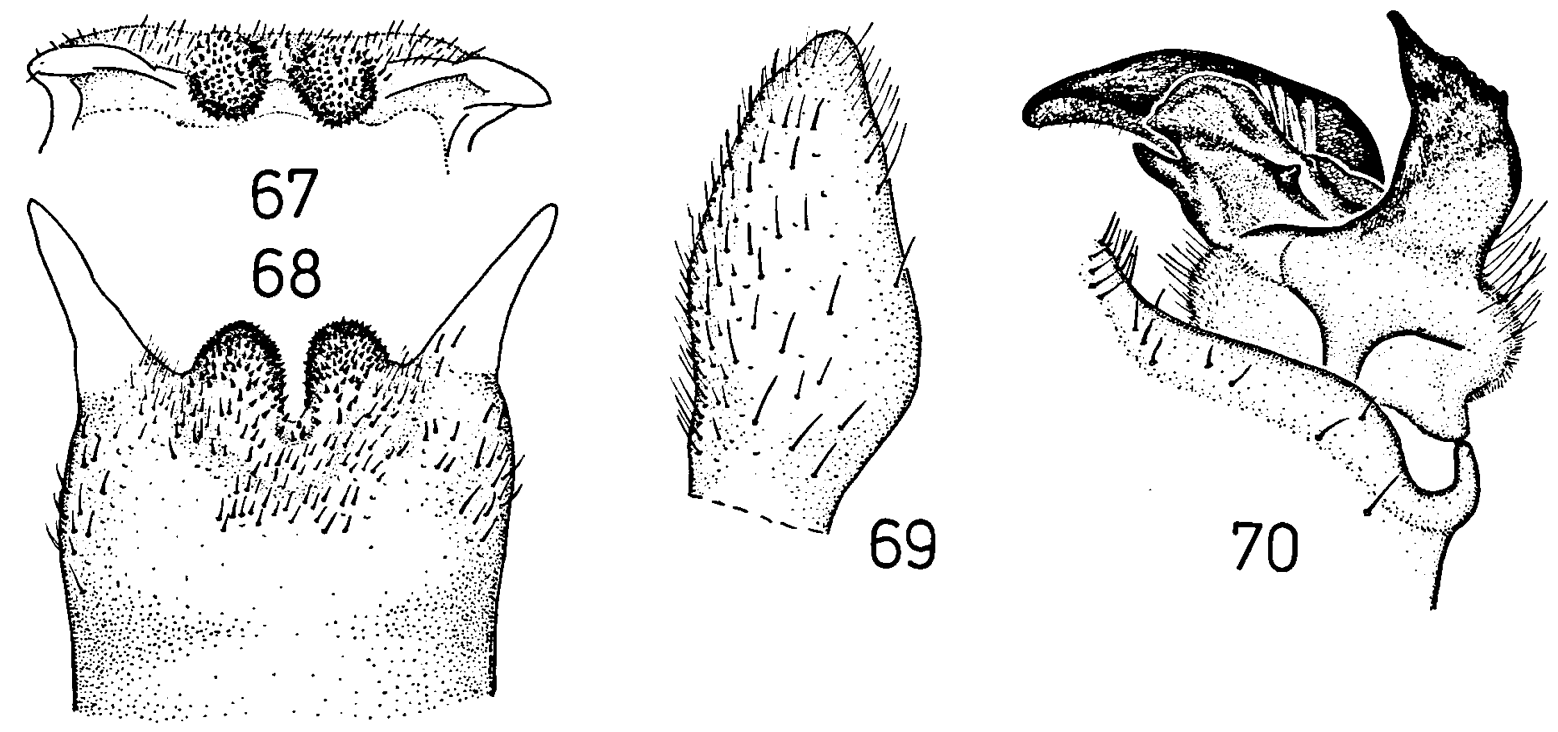

Figs. 67-70. T. (A.) cypriensis spec. nov. ( $\sigma^{\circ}$ holotype from Cyprus): 67, $\sigma^{\circ} \mathrm{T} 9$, caudal view; 68, $\sigma^{\circ} \mathrm{T} 9$, dorsal view; 69 , ơ Od, lateral view; 70, ơ Id, lateral view.

Thorax: Wing base light; S1 rectangular; S2 triangular, thinly connected along cu with S4; stigma dark brown; beyond stigma in R3 cell and $\mathrm{R} 4+5$ cell some small whitish spots; the posterior half of the discoid cell coloured brown. Abdomen: Male: the two medial projections of tergite 9 more rounded than in $T$. doriae, the lateral projections longer and narrower (figs. 67, 68); Od lanceolate (fig. 69); Id1 concave at the base, the apex posteriorly crenated as in $T$. doriae, but anteriorly grown out into a point; Id2 short and compact, with the robust apex rounded dorsally; at the lateral side a short thorn-like protuberance; at the inner side 5 spine-like setae; the sensory field situated at the posterior base of the Id2; Id3 broader than in $T$. doriae with a humped dorsal side; Id4 small and pubescent, short and almost fused with Id2 (fig. 70).

Female unknown.

\section{Distribution (map 4)}

Known from Cyprus only.

\section{Biology}

Period of flight and altitude unknown.
13. Tipula isparta spec. nov.

(Figs. 71-76)

Material examined. - Holotype: $\sigma$ from Turkey, labeled: "Turkije, Isparta, Egridir, 950 m, 16-VIII-1980, fam. H. v. Oorschot" (ZMA).

Paratypes: $2 \sigma^{\circ} \circ$ labeled as the holotype (ZMA); $1 \sigma^{\circ, 1}$ Q Turkey, W. of Anamûr, 14-VI-1965, Kumerloeve * Mittendorf leg. (MAK); 1 \& Turkey, Bütücsk, 20-X-1949, Kosswig leg. (MAK).

Other material: $1 \sigma^{\circ}, 1$ \&, Cyprus, Lapithos, 24-X-1932, leg. Th. Shiakides (BMNH), see discussion.

\section{Description}

Length: $\sigma$ 23-27 mm, \& 32-36 mm. Wing length $\left(\sigma^{\circ}, \$\right)$ : $25-30 \mathrm{~mm}$.

Head: Scape brown with a dark apical band; flagellar segments greyish yellow; palps dark brown at base, yellow-brown at apex.

Thorax: Wing: S1 trapezoid; base of R3 beyond stigma lightly coloured; R $4+5$ beyond stigma brown, near $m 1+2$ spotted white, white towards margin with a small dark spot at wing margin; M2 cell almost entirely coloured brown.

Abdomen: Male: medial projection of tergite 9 narrow and high, more robust than in $T$. doriae, the central incision rather deep (fig. 72); Od 


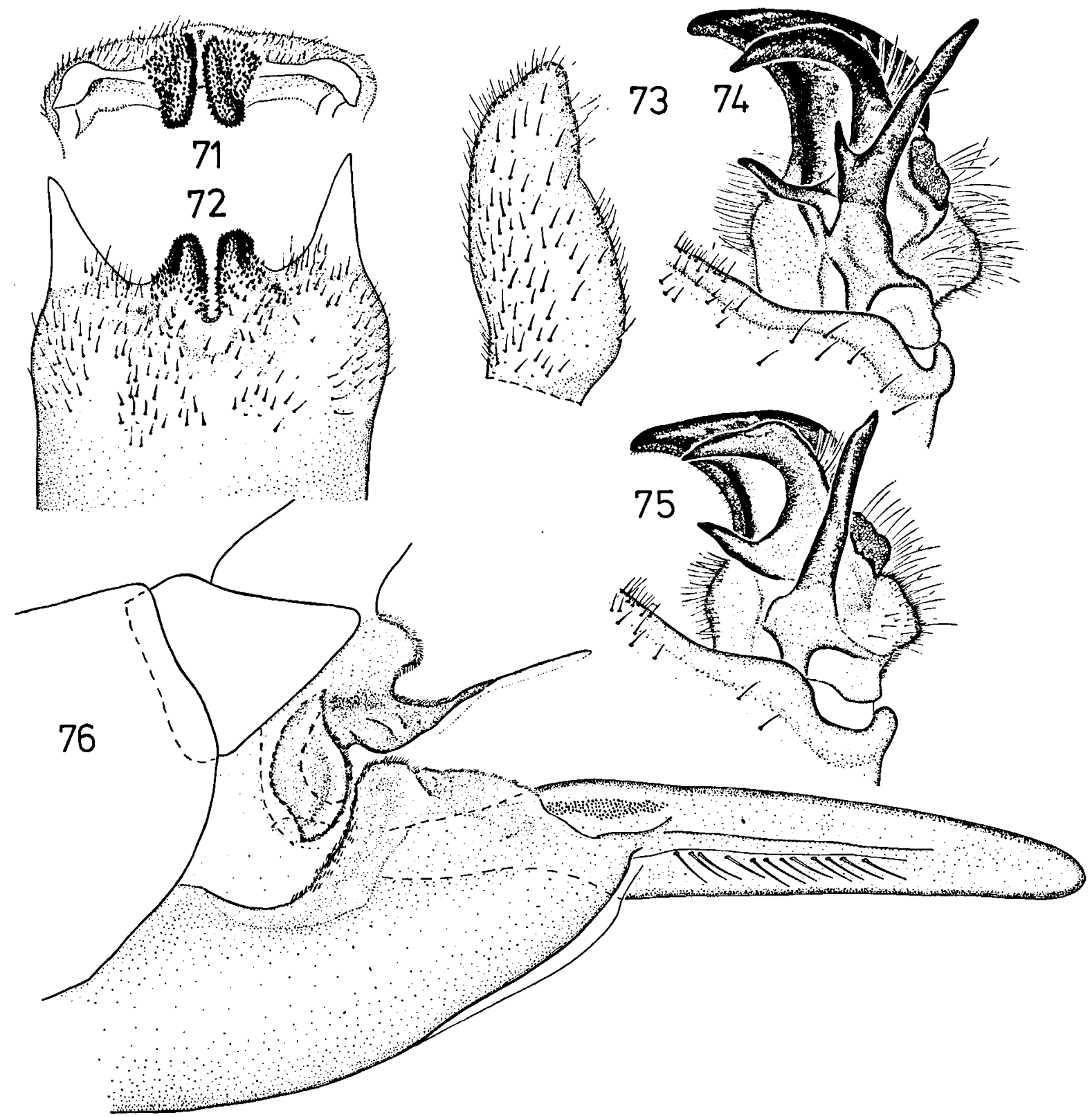

Figs. 71-76. T. (A.) isparta spec. nov. ( $\sigma^{\circ}$ paratype from Isparta, Turkey, except for fig. 75; $\$$ paratype from Bütücsk, Turkey): 71, o' T9, caudal view; 72, $\sigma^{\circ} \mathrm{T} 9$, dorsal view; 73, $\sigma^{\circ}$ Od, lateral view; 74, $\sigma^{\circ}$ Id, lateral view; 75, $\sigma^{\circ}$ Id of Cypriot specimen from Lapithos, Cyprus, lateral view; 76, $९$ ovipositor, lateral view.

oblong, narrow and pointed, larger than in 7 . cypriensis (fig. 73); Id1 cylindrical and very elongate, with a smaller projection at about $1 / 3$ of the length; the base of Id2 enlarged as in $T$. cypriensis, bearing the sensory field posteriorly, but the apex of Id2 elongate cranially, the pointed tip bent down, the inner side with 6 spine-like setae; Id3 very broad at base with the apical half shorter and more robust than in $T$. doriae and T. cypriensis; Id4 short cylindrical and pointed, longer than in $T$. cypriensis, with 1 seta at the dorsal side (fig. 74). 
Female: ovipositor as in fig. 76; the hypovalva long and lanceolate; the upper margin of sternite 8 hirsute and strongly developed just before the hypovalva, but not sclerotized as in $T$. doriae; the membranous connection between tergite 9 and the fused valvulae strongly vaulted sidewards; fused valvulae narrow with elongated tip.

\section{Distribution (map 4)}

Central and southern Turkey, Cyprus.

\section{Biology}

Period of flight June until October. Recorded altitude $950 \mathrm{~m}$.

\section{Discussion}

This species is known from three localities in Turkey. All specimens have identical hypopygia, but range in colouration from lighter to darker. From Cyprus one male and one female are known labeled "Cyprus, Lapithos, 24-X-1932, leg. Th. Shiakides"' (in $\mathrm{BMNH}$ ). They resemble the southern Turkish specimens in colouration and wing pattern, but Id 1 is more slender, Id2 more irregular and Id4 shorter and thicker (fig. 75); the female's ovipositor is as in the Turkish specimens, except that the apex of the fused valvulae is shorter. Although this material might represent a separate subspecies, I refrain from naming it until more material becomes available.

\section{Tipula (Acutipula) repanda subgroup}

This subgroup, containing three closely related species, is restricted to northwest Africa and the Iberian peninsula. A very distinct difference with the other subgroups is found in the male tergite 9 which possesses only one medial projection, whereas the apex of the intromittent organ is bispicate (fig. 9). The females have the upper margins of sternite 8 evenly curved and occluding at the outer side of the membranous connection between sternite 9 and the fused valvulae.
14. Tipula repanda Loew, 1864

(Figs. 77-81)

Refs.: Loew, 1864: 129-130; Mannheims, 1952: 104, fig. 57; Savtshenko, 1961: 416, fig. 253; Theowald, 1978b: 365; Theowald : Oosterbroek, 1981: 34.

Material examined. - This species was described by Loew after $1 \sigma^{\prime}$ and $2 \& \&$ from southern Spain. The type-material has not been examined by the author. The type-specimens are preserved in the Loew collection in Berlin (Humboldt-Universität - Museum für Naturkunde).

Loew's description and the figures given by Mannheims (1952) and Savtshenko (1961) distinctly agree with the material examined $\left(64 \sigma^{\circ} \circ, 32\right.$ \& $)$ from the following countries: France (Hérault); Spain (Gerona, Léon, Palencia, Santander, Burgos, Segovia, Avila, Madrid, Cuenca, Teruel, Jaen); Portugal (Algarve, Manteigas).

\section{Description}

Length: $\sigma^{\circ}$ 19-26 mm, क 24-34 mm. Wing length $\left(\sigma^{\circ}, \%\right)$ : $18-25 \mathrm{~mm}$.

Head: Scape yellow-brown; flagellar segments dark brown throughout the apical end; palps light brown; eye distance ventrally about as long as the diameter of the scape.

Thorax: Wing: S1 trapezoid; S2 triangular; R3 cell with white tip; $M$ cells with only small dark spots near wing margin.

Abdomen: Male: tergite 9 with only one medial projection (figs. 77, 78); Od as in fig. 79; Id1 long, cylindrical and curved forwards; Id2 broad and swollen at the base, with on top of the caudal part a projection which varies from short and blunt (fig. 80a) to long and tapering; between Id1 and Id2 a strongly hirsute swelling; Id3 falcate with 6-8 large setae near the apex; Id4 cylindrical and pointed, dorsally either with 4-6 setae (fig. 80b) or with a projection (fig. 80).

Female: ovipositor as in fig. 81; base of hypovalva with two sclerotized plates underneath the fused valvulae.

\section{Distribution (map 5)}

Iberian peninsula and France. Only one male is known from the Netherlands (Zeeland, Valkenisse, 16-VI-1960, Van Aartsen, ZMA). It is not known whether this species really oc- 


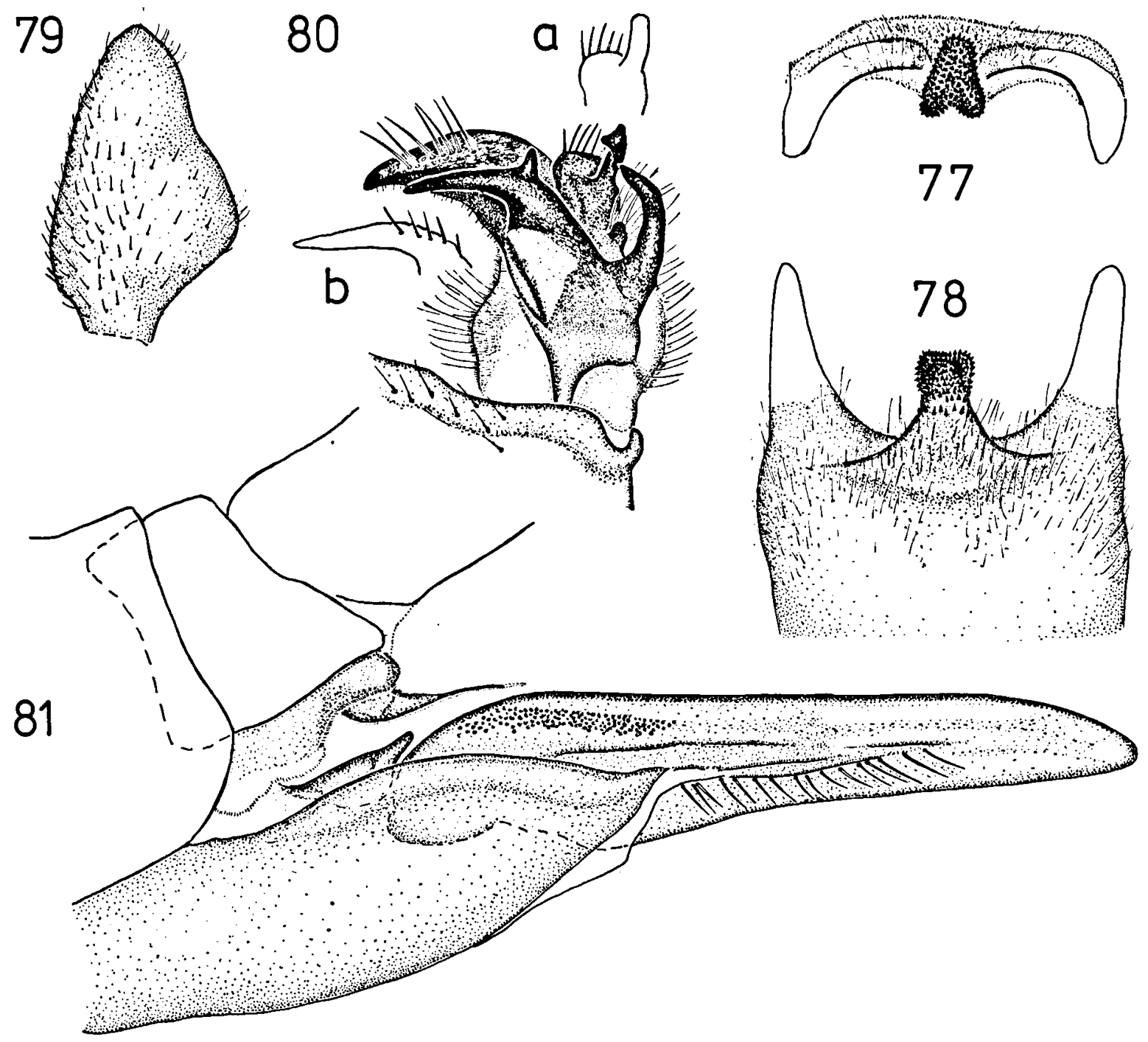

Figs. 77-81. T. (A.) repanda Loew, 1864 ( $\sigma, \odot$ from Teruel, Spain): 77, $\sigma$ T9, caudal view; 78, $\sigma^{\circ}$ T9, dorsal view; 79, $\sigma^{\circ}$ Od, lateral view; 80, $\sigma^{\circ} \mathrm{Id}$, lateral view; $80 \mathrm{a}, \sigma^{\circ} \mathrm{Id}$, variation in shape of Id part 2; 80b, $\sigma^{\circ}$ Id, variation in shape of Id part $4 ; 81$, ovipositor, lateral view.

curs in that part of the Netherlands, or that it has been introduced. It is almost certain that this specimen was collected there instead of being wrongly labeled.

\section{Biology}

Period of flight from June until October. Recorded altitudes are around $1600 \mathrm{~m}$.

\section{Discussion}

The difference in Id4 between the specimens is roughly restricted to two areas: the northern specimens have the hooked projection, the southern specimens possess only a few setae. No other differences can be found among the males. Therefore these two forms are not considered as two different subspecies.

15. Tipula triangulifera Loew, 1864

(Figs. 82-86)

Refs.: Loew, 1864: 130-131; Czerny \& Strobl, 1909: 135; Mannheims, 1952: 105, fig. 59; Savtshenko, 1961: 416, fig. 253; Theowald, 1978b: 365; Theowald \& Oosterbroek, 1981: 34 . 
Material examined. - Type-material: Not examined by the author. Loew described this species in 1864 with emphasis on the wing pattern. Many $T$. repanda specimens from southern Spain, however, show the same pattern as $T$. triangulifera. Therefore this pattern of the wing is not a reliable character to separate $T$. triangulifera from $T$. repanda. The interpretation of $T$. triangulifera followed here is mainly based on Mannheims (1952) who has examined the holotype. The holotype is preserved in the Loew collection in Berlin (Humboldt-Universität - Museum für Naturkunde).

Other material (all from Spain): $1 \sigma^{\circ}, 1 \%$, Granada, Sierra Nevada, 23-VII-1953, C. A. W. Jeekel leg. (ZMA); 1 ơ, 1 \& Nerpio, VIII-1950, Andrew leg. (MAK); 1 O Durcal, Granada, Peris Torres leg. (MAK).

\section{Description}

Length: $\sigma^{*} 21-25 \mathrm{~mm}$, \& $27-32 \mathrm{~mm}$. Wing length $\left(\sigma^{\circ}, \%\right): 20-28 \mathrm{~mm}$.

Head: Antennae light brown; verticils about twice as long as the flagellar segments; ventral distance between the eyes about as long as the diameter of the scape.

Thorax: Wing: pattern about the same as in $T$. repanda except $\mathrm{S} 3$, which is somewhat triangular; the anterior base of the $\mathrm{R} 4+5$ cell is brown, the posterior half to the wing margin is

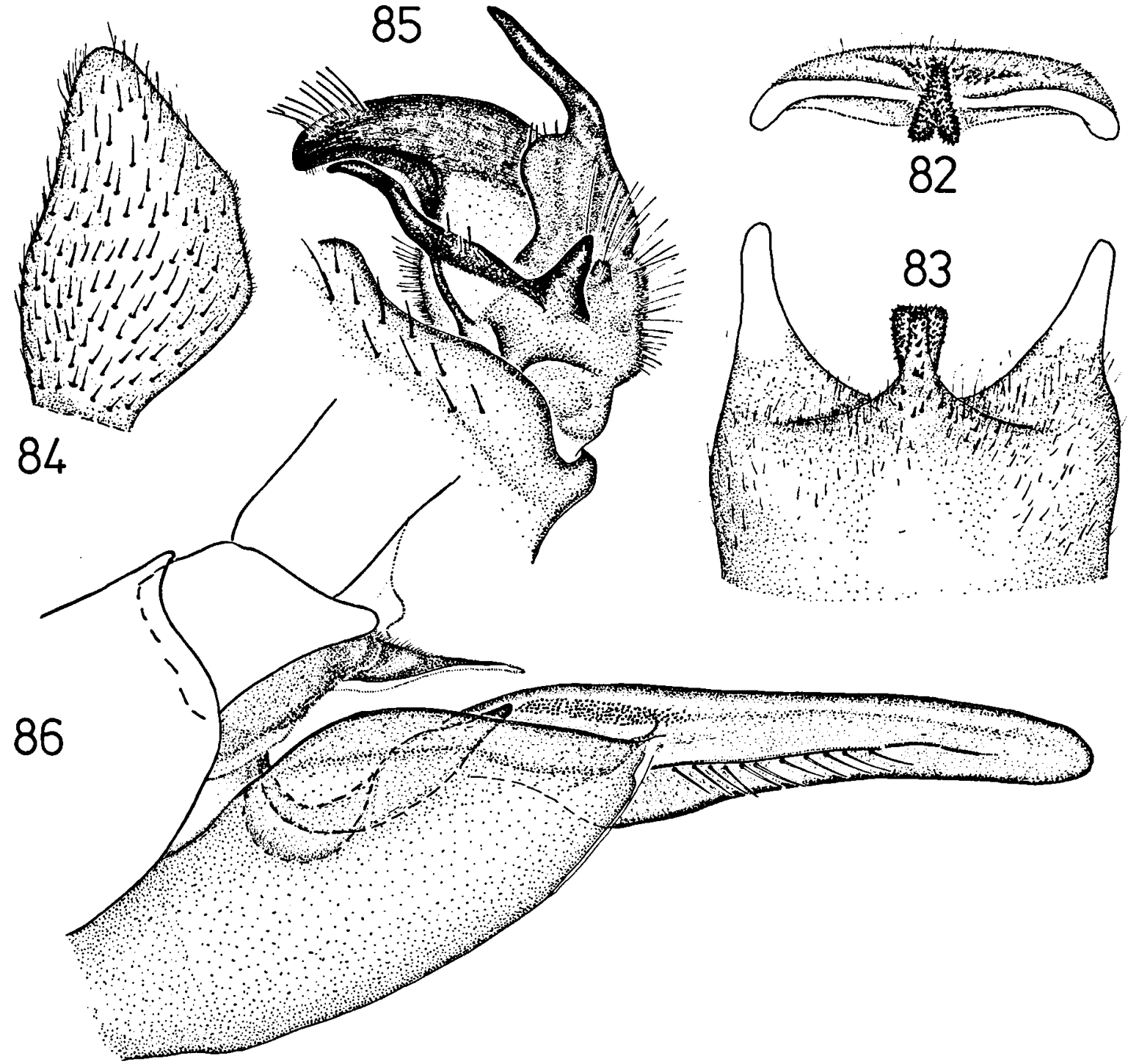

Figs. 82-86. T. (A.) triangulifera Loew, 1864 ( $\sigma^{\circ}, \odot$ from Granada, Spain): 82, $\sigma$ T9, caudal view; 83, $\sigma^{\circ}$ T9, dorsal view; $84, \sigma \circ$ Od, lateral view; 85 , $\sigma$ Id, lateral view; 86 , $९$ ovipositor, lateral view. 
white; $\mathbf{M}$ cells about half coloured, M1 brown only at wing margin and along the vein $\mathrm{m} 2$.

Abdomen: Male: tergite 9 as in $T$. repanda but the medial projection is more slender and narrower (figs. 82, 83); Od as in fig. 84; Id1 present as a short conical sclerotized projection; Id2 with a broad base, at the inner side 5-7 spinelike setae above a large sensory field, and dorsally a long projection; Id4 long and slender (fig. 85).

Female: ovipositor as in fig. 86 ; the sclerotized plates in front of the hypovalva underneath the fused valvulae are much larger than in $T$. repanda and more situated towards the sides.

\section{Distribution (map 5)}

Endemic to the south of Spain.

\section{Biology}

Period of flight July until September. Altitudes recorded are around $1600 \mathrm{~m}$.

16. Tipula repentina Mannheims, 1952

(Figs. 87-91)

Refs.: Mannheims, 1952: 104-105, fig. 58; Vaillant, 1956: 237, 240; Savtshenko, 1961: 417, figs. 253-254; Theowald \& Oosterbroek, 1980: 182.

Material examined. - Mannheims described this species after one male, labeled: "Marokko, Gr. Atlas, Tachdirt, 2200-2700 m., 2-10 VII 33, Zerny leg." (NMW).

The description and the figures given by Mannheims (1952) distinctly agree with the material examined: 35 $\sigma^{\circ} \sigma^{\circ}, 15 \& \&$ from the following localities in Morocco: Androment (1 $\left.\sigma^{\circ}\right)$, M'Goun (1 $\left.\sigma^{\circ}\right)$, Ifrane (1 $\left.\sigma^{\circ}\right)$ Tadmant (4 $\sigma^{\circ}, 3 \propto$, 3 ), Tizi-N-Test $\left(1 \sigma^{\prime}, 1\right.$ \&), Setti Fatma (3 ○ ९), Oukaïmeden (16 $\sigma^{\circ}, 6$ \& ९), Tizi-N-Tichka (11

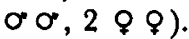

\section{Description}

Length: $O$ 20-27 $\mathrm{mm}$, \& 24-33 mm. Wing length ( $\sigma^{\circ}, \%$ ): 20-29 mm.

Head: Scape light brown; flagellar segments brown to dark brown at the apex; verticils long, up to two times the length of the flagellar segments; palps brown, lighter towards the apex; the distance between the eyes ventrally about two times the diameter of the scape.

Thorax: Wing: S1 separated from S2 by a bright trapezoid band; S2 triangular, shortly connected with S4 along cu vein; S3 at wing tip larger than in $T$. repanda and $T$. triangulifera, also colouring the top of the $M$ cells; the proximal half of $R 4+5$ brown; the spots in the $M$ cells are small, about $1 / 3$ of the area of the cells. Abdomen: Male: the lateral projections of tergite 9 are broad at the base and shorter than in $T$. repanda and $T$. triangulifera; the medial projection is also broad and robust, the apex blunt (figs. 87, 88); Od as in fig. 89; Id1 much larger than in $T$. repanda; Id2 with a large and robust base, posterior with a long projection bearing many setae; Id4 larger than in $T$. repanda and T. triangulifera (fig. 90).

Female: ovipositor as in fig. 91, the upper margin of sternite 8 large and strongly bent downwards cranially.

\section{Distribution (map 5)}

Known only from the Grand Atlas mountains of Morocco.

\section{Biology}

Period of flight June until September. Recorded altitudes are up to $2900 \mathrm{~m}$.

\section{Tipula (Acutipula) anormalipennis subgroup}

This subgroup contains the species anormalipennis only. It has a more or less isolated position within the $T$. maxima group s.l. because of the lack of teeth at the male tarsal claws, the reduced wings, the elongated discoid cell in the wings, the short bispicate shape of the intromittent organ (fig. 9), the short cerci and the shape of the hypovalva of the female.

\section{Tipula anormalipennis Pierre, 1924}

(Figs. 92-96)

Refs.: Pierre, 1924: 90-91, figs. 49-53; Mannheims, 1952: 103-104, fig. 56; Vaillant, 1956: 237; Savtshenko, 1961: 415, fig. 251; Theowald \& Oosterbroek, 1980: 182. 


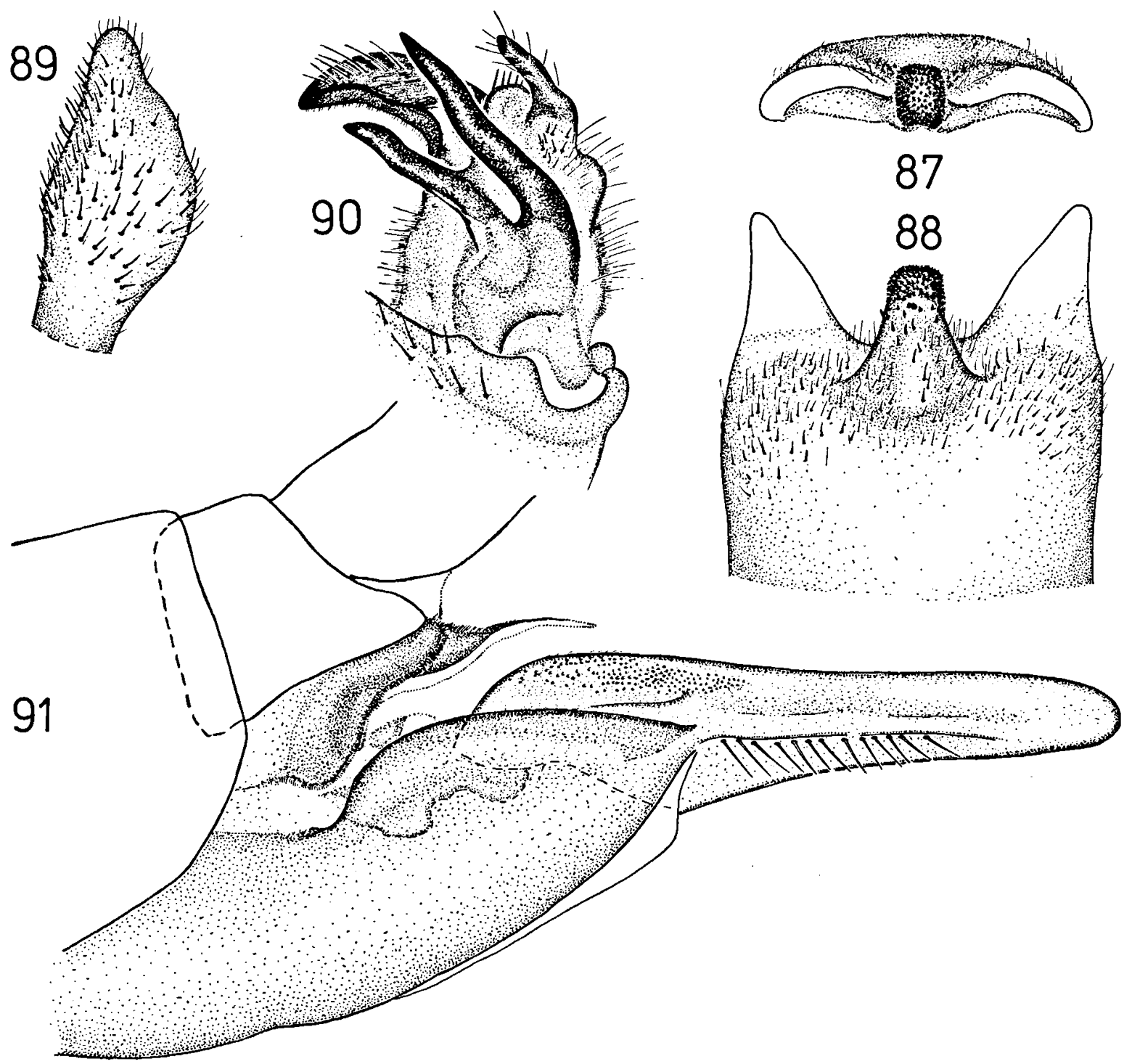

Figs. 87-91. T. (A.) repentina Mannheims, 1952 ( $\sigma^{\circ}, \propto$ from Tizzi-N-Tichka, Morocco): 87, $\sigma^{\circ}$ T9, caudal view; 88, $\sigma^{*}$ T9, dorsal view; 89 , o Od, lateral view; 90 , o* Id, lateral view; 91 , $९$ ovipositor, lateral view.

Material examined. - Type-material: Holotype: $\sigma$ from Morocco, labeled: "Maroc, Grand Atlas, Ht. Imminen, Alluaud leg." (MNHNP).

Other material (all from Morocco): $1 \sigma^{\circ}$, labeled as the holotype (MNHNP); 1 $0^{\circ}$, Oukaïmeden, 2500-2800 m, 12/22-VII-1977, Van Oorschot, Houkes \& Oosterbroek leg. (ZMA); $1 \sigma^{\circ}$, Atlas, Arround, $1950 \mathrm{~m}, 24 / 25-\mathrm{VI}-30$, Ebner leg. (NMW); 2 o $\sigma^{\circ}, 1$ \%, Oukaïmeden, 5-VI-1954, Vaillant leg. (MNHNP, MAK); $20^{\circ} 0^{\circ}, \mathrm{Dj}$. Toubkal, Tachdirt, $2500 \mathrm{~m}, 15 / 31$-VIII-1938, R. Paulian \& A. Villiers leg. (MNHNP).

\section{Description}

Length: $\sigma^{\circ} 16.5-20 \mathrm{~mm}$, ९: $26 \mathrm{~mm}$. Wing length $\left(\sigma^{\circ}\right.$, \&): $11.5-17.5 \mathrm{~mm}$.

Head: Antennae dark brown; rostrum short, about $1.5 \times$ the length of the scape; nasus and rostrum grey-brown; the ventral distance between the eyes is 3-3.9 times the diameter of the scape. 
Thorax: Both male and female without a medial and a basal tooth-like projection on the tarsal claws; wing very small, less conspicuously coloured than in other species of the maxima group; discoid cell elongate; tip of R3 cell light; the basal half of $\mathrm{R} 4+5$ cell brown; $M$ cells with only small brown spots at the wing margin.
Abdomen: Male: tergite 9 with pointed lateral projections, the medial ones conic and rounded (figs. 92, 93); Od as in fig. 94; Id1 nearly unsclerotized, brownish yellow; Id2 broad at the base, with caudally a large tapering projection; Id3 falcate as in the $T$. repanda subgroup with dorsally 4-6 setae; Id4 large, pointed and slightly curved (fig. 95).

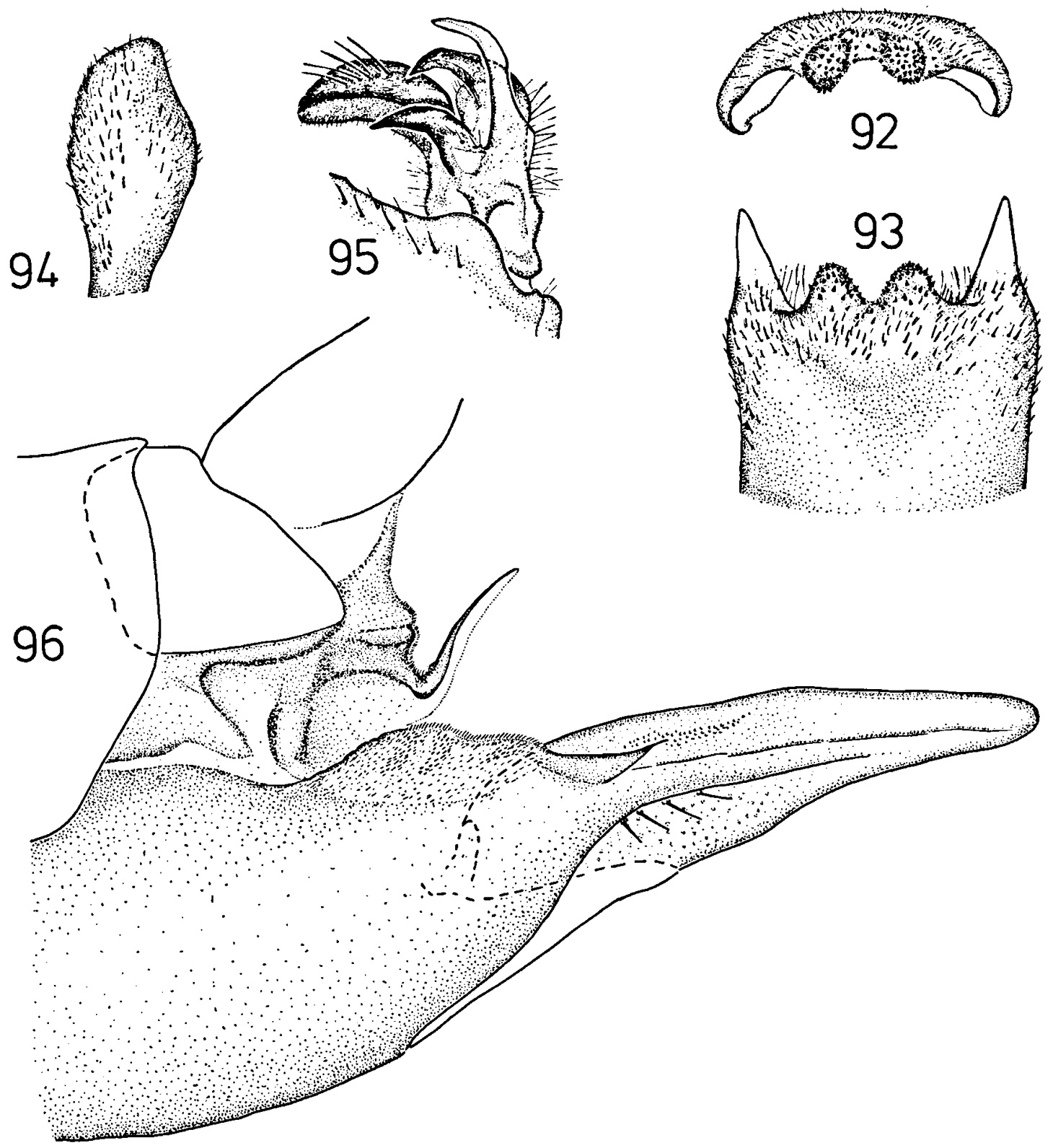

Figs. 92-96. T. (A.) anormalipennis Pierre, 1924 ( $\sigma$ from Ht. Imminen, Morocco; $\odot$ from Oukaïmeden, Morocco): 92 , ơ T9, caudal view; 93, ơ T9, dorsal view; 94, $\sigma$ Od, lateral view; 95, $\sigma$ Id, lateral view; 96, $\$$ ovipositor, lateral view. 


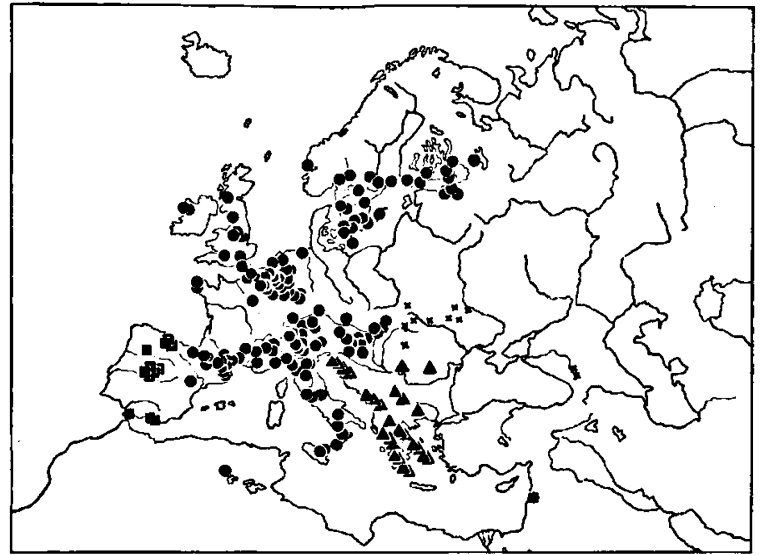

Map 1. Distribution of $T$. (A.) maxima maxima ( $), T$. (A.) maxima pseudogigantea ( $\square), T$.(A.) maxima balcanica (A), $T$.(A.) libanica $\left(^{*}\right)$. Crosses represent data of Savtshenko, 1961.

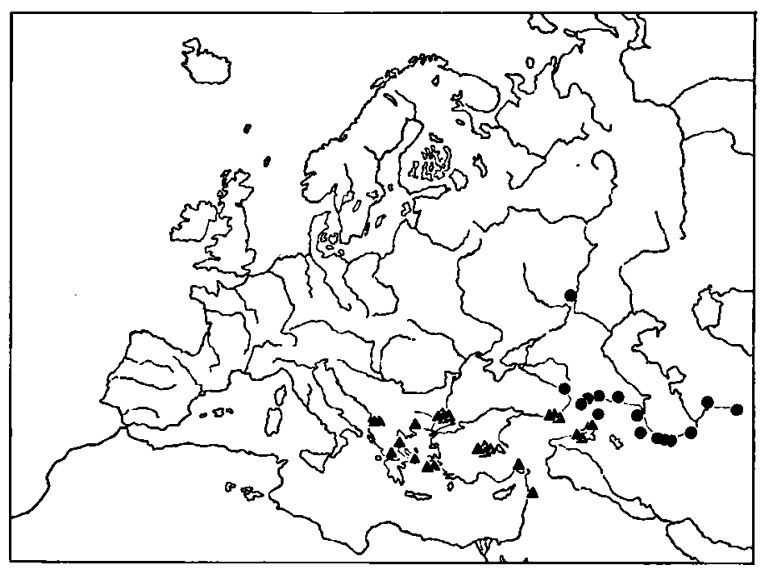

Map 2. Distribution of $T$.(A.) transcaucasica transcaucasica (๑) and T.(A.) transcaucasica latifurca ( $\mathbf{\Delta})$.

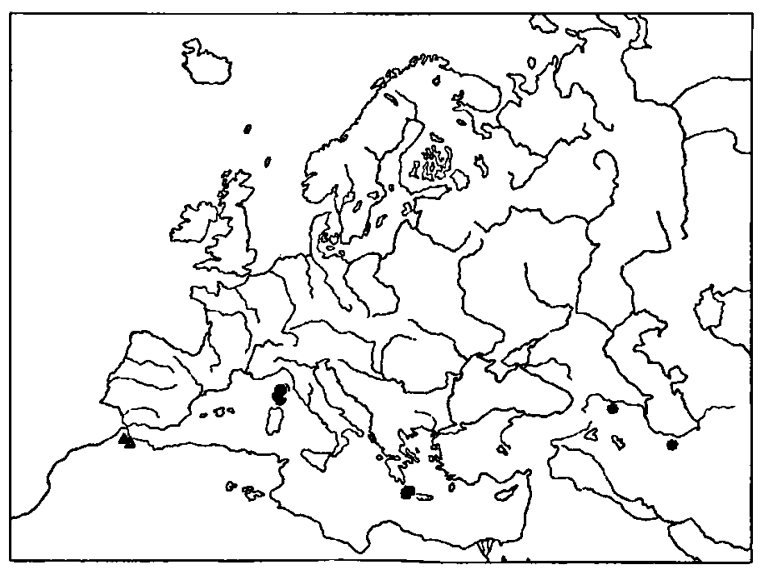

Map 3. Distribution of $T$.(A.) corsica ( ), T.(A.) rifensis (A), T.(A.) cretensis $(\square)$ and $T$.(A.) macra $\left(^{*}\right)$.

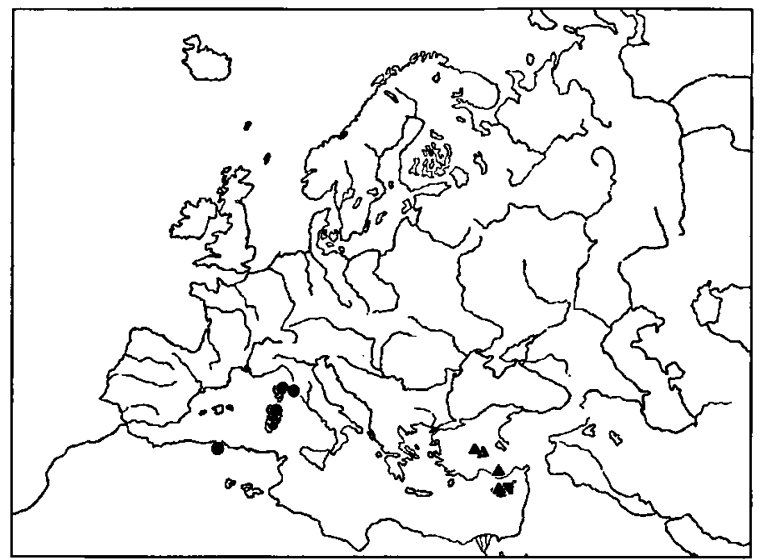

Map 4. Distribution of $T$.(A.) doriae (@), T.(A.) isparta (A) and $T$.(A.) cypriensis ( $\mathbf{\square})$.

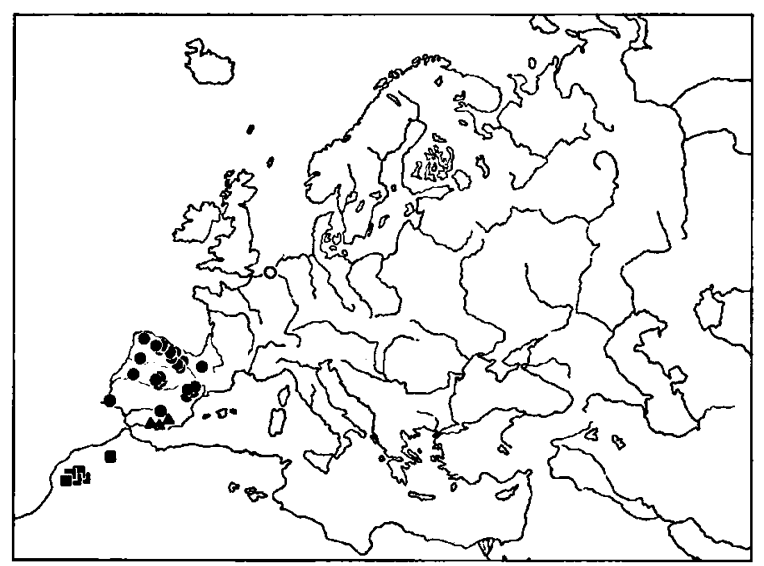

Map 5. Distribution of $T$.(A.) repanda $(\bullet, \circ$ see text for locality in the Netherlands), $T .(A$.$) triangulifera (\mathbf{\Delta})$ and $T$.(A.) repentina ( $\square$ ).

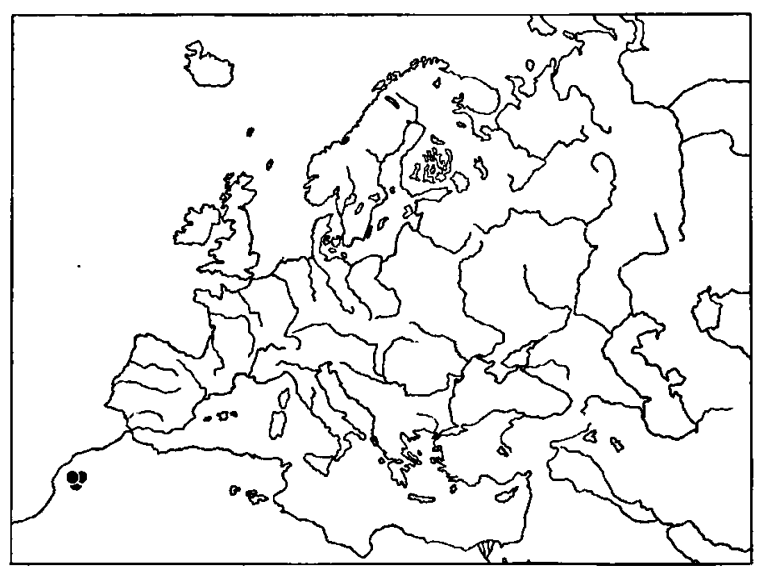

Map 6. Distribution of T.(A.) anormalipennis ( $\bullet$ ). 
Female: ovipositor as in fig. 96, with short cerci, almost as long as the hypovalva; the hypovalva lanceolate and with few hairs on the lateral sides; apex of fused valvulae elongate.

\section{Distribution (map 6)}

Known from the Grand Atlas mountains of Morocco only.

\section{Biology}

Period of flight from June until September. Recorded altitudes are up to $2900 \mathrm{~m}$.

\section{ACKNOWLEDGEMENTS}

For the loan of material I am much indebted to the following institutions and persons: British Museum (Natural History), London (P. S. Cranston; thanks are also due for his research in the files of the British Museum); Muséum National d'Histoire Naturelle, Paris (L. Matile); Museum of Zoology and Entomology, Lund (R. Danielsson); Naturhistorisches Museum, Wien (A. Kaltenbach); Rijksmuseum van Natuurlijke Historie, Leiden (P. J. van Helsdingen); Zoologisches Forschungsinstitut und Museum Alexander Koenig, Bonn (H. Ulrich); Zoological Museum, Helsinki (B. Lindeberg).

Valuable material was gratefully received from C. Dufour (Neuchâtel) and H. van Oorschot (Amsterdam) and $\mathrm{H}$. Malicky (Lunz).

I am very much obliged to Miss. A. Valý (Zoological Department of the Hungarian Natural History Museum, Budapest) and W. Krzemińsky (Polish Academy of Sciences, Kraków) for the identification of specimens and the detailed information received. Finally, I am very grateful to Theowald van Leeuwen and Pjotr Oosterbroek for their enthusiastic support, criticism and valuable advices, and to the technical and administrative staff of the Institute of Taxonomic Zoology, Amsterdam, especially to G. Verlaan for (p)repa(i)ring many of the specimens studied.

\section{REFERENCES}

CaSPERs, N., 1977. Emergenz-Untersuchungen an einem Mittelgebirgsbach bei Bonn: I, Tipuliden-Emergenz 1976. Verh. Ges. Ökologie, Kiel, 1977: 201-205.

Czerny, L. \& G. Strobl, 1909. Spanische Dipteren, III. Verh. zool.-bot. Ges. Wien, 59: 121-246.

Dobson, R. M., 1974. Observations on the spatial distribution of flying Tipulinae (Diptera: Tipulidae) in Scotland. J. anim. Ecol., 43: 513-519.

Dufour, Сн., 1980. Die Insektenfauna des Hochmoores Balmoos bei Hasle, Kanton Luzern. VI, Diptera 1: Tipulidae (Schnaken). Entom. Ber. Luzern, 4: 1517.
ERhan, E. \& BR. Theowald, 1961. Tipulidae of Roumania. Ent. Ber., Amst., 21: 245-252.

Fabricius, J. C., 1775. Systema entomologiae, sistens insectorum classes, ordines, genera, species, adiectis synonymis, locis, descriptionibus, observationibus: [i-xxxii], 1-832 (Libraria Kortii, Flensburgi et Lipsiae).

Fisher, H., 1952. 44 Neue Tipuliden (Diptera) für Schwaben. Ber. naturf. Ges. Augsburg, 5: 119-124.

FreEMAN, B. E., 1967. Studies on the ecology of larval Tipulinae (Dipt. Tipulidae). J. anim. Ecol., 36: 123-146.

-, 1968 . Studies on the ecology of adult Tipulidae (Diptera) in southern England. J. anim. Ecol., 37: 339-362.

Goetghebuer, M. A. Tonnoir, 1921. Catalogue raisonné des Tipulidae de Belgique. Bull. Soc. ent. Belg., 3: 105-125.

Hancock, E. G., 1979. The craneflies (Diptera: Tipulidae) in Bradford Museum collections. Naturalist, 104: 23-29.

Hartig, F., 1971. Contributo alla conoscenza dei Tipulidi e Limoniidi in Italia. Entomologica, Bari, 7: 123-135.

Hemmingsen, A. M., 1952. The oviposition of some cranefly species (Tipulidae) from different types of localities. Vidensk. Meddr. dansk naturh. Foren., 114: $365-430$.

- , 1962. Copulatory adaptations of male hypopygium to female tergal ovipository valves (Cerci) in certain Crane-flies (Tipulidae). Vidensk. Meddr. dansk naturh. Foren., 124: 135-163.

Herbst, J. F. W., 1784. Kurze Einleitung zur Kenntnis der Insekten, für ungeübte und Anfänger, [1]: [i-vi], 1-278, [1-12], pls. [I], IA-XLIII (G. A. Lange, Berlin und Stralsund).

KidD, L. N., 1954. Notes on some Derbyshire Craneflies. J. Soc. Br. Ent., 5: 86-87.

Lackschewitz, P., 1927. Revision der Gimmerthalsen und Sintenisschen Tipuliden. KorrespBl. NaturfVer. Riga, 59: 1-8.

-_, 1933. Revision der in Siebke's Catalogus Dipterorum angeführten Tipuliden. Norsk ent. Tidsskr., 3: 238-255.

Linnaeus, C., 1758. Systema naturae per regna tria naturae, secundum classes, ordines, genera, species, cum characteribus, differentiis, synonymis, locis (ed. 10), 1: [i-iv], 1-823, [1] (L. Salvii, Holmiae).

Loew, H., 1864. Tipula sinuata und ihre nächsten Verwandten. Wien. ent. Monatschr., 8: 128-131.

Lundström, C., 1907. Beiträge zur Kenntnis der Dipteren Finlands, 2. Tipulidae. Acta Soc. Fauna Flora fenn., 29 (2): 1-27.

Mannheims, B., 1950. Über Sammeln, Vorkommen und Flugzeiten mitteleuropäischer Tipuliden (Dipt.). Bonn. zool. Beitr., 1: 92-95. 
, 1952. Tipulidae. A: Westpalaearktische Arten. Fliegen palaearkt. Reg., $3(5,1)$ (15. Tipulidae): 65112.

- -, 1953. Zur Kenntnis der Tipuliden Italiens. Ricerche zoologiche sul Massiccio del Polino, VII. Annuar. Ist. Mus. Zool. Univ. Napoli, 5 (4): 1-8.

-_, 1954a. Die Tipuliden Griechenlands. Bonn. zool. Beitr., Sonderband 1954 (1): 149-182.

ent., 34: 29-50.

- -, 1964. Tipuliden aus Iran (Dipt.) (Ergebnisse der entomologischen Reisen Willi Richter, Stuttgart, im Iran 1954 und 1956 - Nr. 44). Stuttg. Beitr. Naturk., 126: 1-7.

--, 1966a. Ergebnisse der Albanien-Expedition 1961 des Deutschen Entomologischen Institutes. 56. Beitrag Diptera: Tipulidae. Beitr. Ent., 16: 489-502.

-_, 1966b. Die Tipuliden Ungarns (Dipt.) aus der Sammlung des Ungarischen Naturwissenschaftlichen Museums. Folia ent. hung., 19: 273-283.

Meddr., 37: 187-190.

Mannheims, B. \& E. Pechlaner, 1963. Die Tipuliden Nordtirols (Dipt.). Stuttg. Beitr. Naturk., 102: 1-29.

Mannheims, B. \& BR. Theowald, 1959. Die Tipuliden Italiens. Memorie Soc. ent. ital., 38: 15-54.

Mannheims, B. A. G. B. Thomas, 1976. Tipulidae s.s. du Sud-Ouest de la France observés à proximité des cours d'eau (Diptera, Nematocera). Annls. Limnologie, 12 (3): 283-286.

Morge, G., 1976. Diptera collectionis P. Gabriel StroblVIII. Beitr. Ent., 26: 339-439.

Nielsen, P., 1933. Bidrag til. en Fortegnelse over Bornholms Insektfauna: Nematocera Polyneura. Ent. Meddr., 18: 239-245.

- , 1941. Bidrag til en Fortegnelse over Bornholms Insektfauna: Nematocera Polyneura. Tillæg 1. Flora Fauna, Silkeborg, 47 (4): 92-96.

Payne, R. M., 1968. The craneflies (Diptera, Tipulidae) of Epping Forest. Entomologist's Gaz., 19: 33-43.

Pierre, C., 1921. Descriptions de deux Tipula nouveaux (Dipt. Tipulidae). Bull. Soc. ent. Fr., 1921: 47-49.

-—, 1924. Tipulidae nouveaux. Encycl. ent., 1: 79-93.

- -, 1926. Tipulidae nouveaux. Encycl. ent., 3: 13-16.

PoDA, N., 1761. Insecta musei graecensis, quae in ordines, genera et species juxta systema naturae Caroli Linnaei digessit: [i-viii], 1-127, [1-12], pls. III (Haeredum Widmanstadii, Graecii; Fascimile-Ed., No. 19, 1915, W. Junk, Berlin).

Puls, J. Ch., 1864. Catalog der Dipteren aus der Berliner Gegend, gesammelt von J. F. Ruthe. Berl. ent. Z., 8: 4.

Riedel, M. P., 1919. Die bei Frankfort (Oder) vorkommenden Arten der Dipteren - (Nematocera Polyneura) - Gattungen der Limnobiidae, Tipulidae und Cylindrotomidae. Ent. Rdsch., 36: 1-41.

- 1 1920, Nematocera polyneura (Dipt.) aus dem Kaukasus. Zool. Jb., 43: 13-22.
Savtshenko, E. N., 1961. Tipulidae. Fauna SSSR, (N.S.) 79 (Diptera, 2) (3): 360-427 (in Russian).

- , 1979. Phylogenie und Systematik der Tipulidae. Translated and revised by BR. THeowald \& G. Theischinger. Tijdschr. Ent., 122: 91-126.

Schrank, F. von Paula von, 1776. Beytraege zur Naturgeschichte: 1-140 (C. Fritsch, Leipzig).

Scopolı, J. A., 1763. Entomologia Carniologica exhibens insecta Carnioliae indigena et distributa in ordines, genera, species varietates methodo Linnaeana: [ixxxii], 1-420, pls. I-XLIII (J. T. Trattner, Vindobonae).

Simova, D., 1959. Beitrag zur Kenntnis der Tipuliden und Limoniiden von Mazedonien (Diptera-Nematocera). Fragm. balcan., 2: 125-135.

-, 1974 . Contribution to the study of craneflies fauna (Tipulidae, Diptera) in Yugoslavia. Zašt. Bilja, 25: 24-30.

- 1 1976. Contribution to the study of craneflies (Tipulidae, Diptera) in Serbia. Arh. biol. Nauka, 28: 147-152.

- , 1977. Dolgonozhni komartsi - Tipulidae (Diptera - Insecta). Fauna na Makedonija, Skopje, 3: 1-198.

- , 1978. Synopsis - Contribution to the study of craneflies (Tipulidae, Diptera) in Slovenia. Biol. Vest., 26 (2): 183-186.

Steward, K. M., 1975. Larvae of Tipulinae in SouthWest Scotland. Glasg. Nat., 19: 181-187.

Strobl, G., 1900. Spanische Dipteren XII. Wien. ent. Ztg., 19: 207-216.

Theischinger, G., 1977. Schnaken aus dem Allgäu (Diptera, Tipulidae). NachrBl. bayer. Ent., 26 (1): 1 -4.

- , 1978. Schnaken (Tipulidae) aus Ober-Österreich (I, Diptera, Nematocera). Jb. oberöst. MusVer., 123 (1): 237-268.

Theowald, BR., 1957. Tweevleugelige insecten. Diptera, 4: De Nederlandse langpootmuggen (Tipulidae). Wet. Meded. K. ned. natuurh. Veren., 24: 1-28.

- , 1971. Die Tipuliden der Benelux-Länder. Tijdschr. Ent., 114: 217-238.

- , 1978a. Tipuliden aus Iran und Afghanistan. Bull. zoöl. Mus. Univ. Amsterdam, 6: 69-77.

- , 1978b. Tipulidae. In: J. Illies ed., Limnofauna Europaea (2. Aufl.): 363-366 (Gustav Fischer Verlag, Stuttgart \& New York).

Theowald, Br. P. Oosterbroek, 1980. Zur Zoogeographie der westpalaearktischen Tipuliden, I. Die Tipuliden von Nordafrika. Beaufortia, 30: 179-192.

- « - 1981. Zur Zoogeographie der westpalaearktischen Tipuliden, II. Die Tipuliden der Iberischen Halbinsel. Beaufortia, 31: 31-50.

TJEDER, B., 1955. Catalogus Insectorum Sueciae. Fam. Tipulidae. Opusc. ent., 20: 229-247.

- - 1965. Faunistic notes on Norwegian Tipulidae (Diptera). Norsk ent. Tidsskr., 13: 41-46.

——, 1967. Kullabergs Nätvinger, näbbsländor, nättsländor och harkrankar. Kullabergs Natur, 12: 1-21. 
TJeder, B. E. KLefBeck, 1946. Insekter fran södra Bohuslän. Ent. Tidskr., 67: 198-209.

Vaillant, F., 1956. Recherches sur la faune madicole (Hygropétrique s.l.) de France, de Corse et d'Afrique du Nord. Mém. Mus. natn. Hist. Nat. Paris, (A) 11: 1-258.
ZANGheri, P., 1969. Repertorio sistematico e topografico della flora e fauna vivente e fossile della Romagna, Tomo III. Memorie Fuori Ser. Mus. civ. Storia Nat. Verona, 1: 1023-1028.

Zetterstedt, J. W., 1851. Diptera Scandinaviae disposita et descripta, 10: 3914-3916 (Officina Lundbergiana, Lundae).

Received: 24 December 1982 